\title{
LOJAS E ARMAZÉNS DAS CASAS DE MORADA PAULISTAS
}

Maria Lucília Viveiros Araúío
Pós-doutoranda FEA-USP'.*

\section{Resumo}

$\mathrm{O}$ artigo analisa as tendências do comércio da capital paulista da primeira metade do século XIX. Propomos fornecer dados sobre o perfil dos proprietários das lojas comerciais e dos gêneros mercantis disponíveis na região, visando a esclarecer questões sobre a diversificação e a especialização do comércio paulista nesse período.

\section{Pallavras-chaves}

Lojas $\bullet$ comércio $\bullet$ negociantes $\bullet$ São Paulo • Oitocentos.

\section{Abstract}

The article analyses the trends of trade in São Paulo in the first half of the $19^{\text {th }}$ century. We provide some on the profile of the owners of the stores and the goods, seeking to clarify questions about diversification and specialization of paulista trade that time.

\section{Keywords}

Shops $\bullet$ merchants $\bullet$ trade $\bullet$ São Paulo $\bullet 19^{\text {th }}$ century.

\footnotetext{
${ }^{1}$ Na FEA-USP, desenvolvo trabalho sobre negócios e negociantes de São Paulo de 1750 a 1850, sob supervisão do prof. dr. José Flávio Motta, com apoio da Fapesp. Agradeço às sugestões bibliográficas do prof. dr. José Luís Cardoso.
} 
Parallélement à ces permanences, l'évolution économique fabrique d'autres formes de boutiques spécialisées. On distingue peu à peu les boutiqueirs qui vendent au poids: les épiciers; ceux qui vendent a l'aune: les drapiers ou tailleurs; ceux qui vendent par pièces: les quincaillers; ceux qui vendent des objects usagés, vêtements ou meubles: les fripiers (Fernand Braudel). ${ }^{2}$

Em Jogo das trocas, Braudel descreve a loja do merceeiro Abraham Dent, de Kirkby Stephen, norte da Inglaterra, que, em 1776, vendia de tudo: chá, açúcar, farinha, vinho, aveia, sabão, uvas, ervilha, condimentos, tecidos, livros, revistas, papel etc. ${ }^{3}$ Era esse o perfil dos comerciantes dos vilarejos, mas nos centros urbanos europeus ocorriam grandes transformações: a fragmentação das funções conduzia lojistas e ambulantes à especialização, ao mesmo tempo em que se acentuavam as hierarquias entre os comerciantes de longa distância e aqueles do comércio interno, e entre os atacadistas e os retalhistas. ${ }^{4}$

Essas inovações podiam ser notadas nas praças de Salvador e Rio de Janeiro, ${ }^{5}$ cidades portuárias onde circulava grande parte dos gêneros do comércio colonial. Entretanto, São Paulo era uma das capitais com menor população na América portuguesa, 24.311 habitantes em 1803. A capitania havia iniciado tardiamente, nas últimas décadas do século XVIII, a produção de açúcar para exportação, e sua população estivera antes ocupada basicamente com o transporte e o comércio de abastecimento das minas. ${ }^{6}$ Nessa época, muitos dos antigos abastecedores

\footnotetext{
${ }^{2}$ BRAUDEL, Fernand. Civilisation materielle, économie et capitalisme, XV-XVIII siècle. T. 2. Les jeux de l'échange. $4^{\mathrm{a}}$ ed. Paris: A. Colin, 1979, p. 51.

${ }^{3}$ Idem, p. 48-50.

${ }^{4}$ Um grupo de historiadores franceses, discípulos de Braudel, vem pesquisando as mudanças da produção, comercialização e dos hábitos de consumo do Ancien Régime baseados em dados dos inventaires après décès. Tomamos de empréstimo parte dessa metodologia, especialmente de: CORNETTE, Joël. La révolution des objets. Le Paris des inventaires après décès $\left(\mathrm{XVII}{ }^{\mathrm{e}}-\mathrm{XVIII}{ }^{\mathrm{e}}\right.$ siècles). Revue d'histoire moderne et contemporaine, jul./set. 1989, p. 483-485. ROCHE, Daniel. Histoire des choses banales: naissance de la consommation dans les societés traditionnelles (XVII ${ }^{\mathrm{e}}$-XIX ${ }^{\mathrm{e}}$ siècle). Paris: Fayard, 1997.

${ }^{5}$ Sobre o comércio oitocentista de Salvador, ver: MATTOSO, Katia M. de Queirós. A cidade do Salvador e seu mercado no século XIX. São Paulo: Hucitec; Salvador: S.M.E.C., 1978; verificar bibliografia sobre o comércio do Rio de Janeiro em: LOBO, Eulália Maria L. Fontes para a história do comércio do Rio de Janeiro. América Latina en la historia econômica. n 9, enero/jun. 1998, p. 65-75. ${ }^{6}$ Sobre o processo de mercantilização de São Paulo no século XVIII, ler: BLAJ, Ilana. Agricultores e comerciantes em São Paulo nos inícios do século XVIII: o processo de sedimentação da elite paulistana. Revista Brasileira de História. São Paulo, v. 18, n. 36, 1998, p. 281-296. BORREGO,
} 
das minas e seus descendentes estabeleceram-se com loja aberta em São Paulo impulsionando a oferta de gêneros.

Os grandes sobrados de taipa foram construídos na área central da capital nos primeiros anos oitocentistas. As lojas, os armazéns e os serviços eram instalados na parte inferior dessas propriedades como extensões das casas de morada; estoques comerciais e trastes domésticos disputavam assim o mesmo espaço. As casas térreas, de comerciantes mais modestos, mantinham as lojas nos corredores ou na sala da frente. Como em Kirkby Stephen, os mercadores paulistas comercializavam todos os gêneros mercantis, inclusive drogas e livros. Havia apenas uma pequena distinção entre lojas de fazendas secas e de molhados. Esses estabelecimentos diversificados asseguravam ao negociante uma freguesia constante e pouco exigente. Porém, após a construção das ferrovias nos anos de $1860,{ }^{7}$ com a afluência dos ricos cafeicultores e dos imigrantes para a capital, surgiram casas comerciais especializadas, especialmente de artigos de luxo. ${ }^{8}$ Ao mesmo tempo, o trabalho tendeu a afastar-se das residências, provocando a dissociação entre vida doméstica e profissional. ${ }^{9}$

Muriel Nazzari estudou as transformações sofridas pela família oitocentista paulista, quando ela perdia o caráter corporativo em favor de posturas mais individualistas. Segundo a historiadora, ao isentar os demais membros da família das responsabilidades financeiras pelos débitos dos negócios, o Código Comercial brasileiro de 1850 teria contribuído para separar os negócios dos assuntos domésticos e para a profissionalização das empresas. ${ }^{10}$

Maria Aparecida de Menezes. A teia mercantil: negócios e poderes em São Paulo colonial (17111765). Tese de doutorado, FFLCH, Universidade de São Paulo, 2006. PETRONE, Maria Thereza. A lavoura canavieira em São Paulo: expansão e declínio 1765-1851 [tese de 1964]. São Paulo: Difel, 1968, continua a obra de síntese da economia canavieira paulista.

${ }^{7}$ Paul Singer relacionou a construção do complexo ferroviário à consolidação da capital como centro político e financeiro no final do século XIX. SINGER, Paul. Desenvolvimento econômico e evolução urbana: análise da evolução econômica de São Paulo, Blumenau, Porto Alegre e Belo Horizonte e Recife. São Paulo: Nacional, 1968.

${ }^{8}$ Barbuy apresentou uma pesquisa sobre as mudanças que ocorreram no espaço comercial nas ruas 15 de Novembro, Direita e São Bento, enquanto M. Luiza Oliveira tratou das estratégias de sobrevivência dos pequenos comerciantes. BARBUY, Heloisa. A cidade-exposição: comércio e cosmopolitismo em São Paulo, 1860-1914. São Paulo: Edusp, 2006. OLIVEIRA, Maria Luiza Ferreira de. Entre a casa e o armazém: relações sociais e experiência de urbanização: São Paulo, 1850-1900. São Paulo: Alameda, 2005.

${ }^{9}$ Sobre o conceito de palacete e superposição do privado ao público na casa burguesa, ler: HOMEM, Maria Cecília N. O palacete paulistano e outras formas urbanas de morar da elite cafeeira. São Paulo: M. Fontes, 1996, capítulo I.

${ }^{10}$ NAZZARI, Muriel. Disapearance of the dowry: women, families, and social change in São 
O estudo tratará das mudanças e permanências do setor comercial em São Paulo nos primeiros decênios do século XIX. Nessa época, a indústria europeia passava por contínuo processo de inovação da produção e dos transportes, com consequente barateamento de seus produtos. ${ }^{11}$ Além disso, as barreiras ao comércio exterior tinham sido suprimidas na América portuguesa desde $1808,{ }^{12} \operatorname{logo}$ o setor podia acompanhar as tendências do "mercado" ${ }^{13}$ Propomos analisar os negociantes paulistas atuantes na capital de 1800 a 1860 e seus estoques, a fim de identificar o grau de diversificação e especialização das casas comerciais dessa fase. $\mathrm{O}$ artigo foi dividido em seções; trataremos das memórias do antigo centro comercial paulista que têm fornecido as bases para a história desse período, faremos uma reflexão sobre a documentação, por fim analisaremos os produtos disponíveis nas lojas e armazéns da cidade. A amostra de preços aventa a redução do valor dos produtos industrializados. A lista desses gêneros sugere a diversificação da sua oferta em casas cada vez mais especializadas. Alguns estabelecimentos permaneceram na família, outras famílias transferiram-se para o setor financeiro ou público e, ao mesmo tempo, novos sobrenomes ocupavam antigos espaços das trocas, sinalizando a ascensão social do imigrante. Comparamos a quantidade de casas comerciais de São Paulo com as similares do Rio de Janeiro para dimensionar o tamanho do setor comercial paulista. Pretendemos com a pesquisa contribuir com novos dados para a discussão da dinâmica do setor comercial e do grupo mercantil na passagem do Brasil colonial para o Império.

\section{Memórias}

Os memorialistas que descreveram a vida econômica e social de São Paulo, do século XVIII até a segunda metade do século XIX, sempre se reportavam

Paulo, Brazil (1600-1900). Stanford: Stanford University Press, 1991, p. 102.

${ }^{11}$ HOBSBAWM, Eric. J. Da revolução industrial inglesa ao imperialismo [1 ${ }^{\mathrm{a}}$ ed. 1968]. Tradução de D. M. Garschagen. Rio de Janeiro: Forense-Universitária, 1978, p. 71.

${ }^{12}$ Foram publicados recentemente dois livros sobre as repercussões políticas e econômicas da abertura do comércio luso-brasileiro às nações amigas: ARRUDA, José Jobson de A. Uma colônia entre dois impérios: a abertura dos portos brasileiros 1800-1808. Bauru: Edusc; São Paulo: C. J. Cortesão, 2008. RICUPERO, Luís Valente de O. (org.). A abertura dos portos. São Paulo: Senac, 2007.

${ }^{13}$ Encontra-se uma reflexão sobre a emergência da cultura do mercado em: MADUREIRA, Nuno Luís. Mercado e privilégios. A indústria portuguesa entre 1750 e 1834. Lisboa: Estampa, 1997. 
ao testemunho dos estrangeiros que visitaram a capital após $1808,{ }^{14}$ ou às recordações dos moradores da urbe daquele século. ${ }^{15}$ Esses panoramas sobre o comércio paulista das primeiras décadas do século XIX costumavam apresentar as mesmas passagens com outras palavras. ${ }^{16}$ Após as publicações do IV centenário da fundação de São Paulo, surgiram obras baseadas em um corpo documental mais amplo. Affonso de Taunay, por exemplo, redigiu quatro volumes sobre a história política e social paulista, fornecendo algumas observações pontuais sobre seu comércio. ${ }^{17}$ Obra de maior fôlego sobre Os comerciantes na sociedade paulistana na primeira metade do século XIX foi produzida por Elizabeth Rabello. ${ }^{18}$ Esta historiadora se propôs a analisar a origem e atuação

\footnotetext{
${ }^{14}$ Sete estrangeiros passaram por São Paulo, entre 1808 e 1850, e publicaram suas lembranças e opiniões sobre diversos aspectos da vida paulista. BEYER, Gustavo. Ligeiras notas de viagem do Rio de Janeiro à capitania de S. Paulo, no Brasil, no verão de 1813... Tradução Alfredo Löfgren. Revista do Instituto Hist. Geog. de S. Paulo. São Paulo, vol. XII, 1970, p. 275-311. D'ALINCOURT, Luiz. Memória sobre a viagem do porto de Santos á cidade de Cuiabá [1830]. São Paulo: Martins, 1953. KIDDER, Daniel P. Reminiscências de viagens e permanências no Brasil [1842]. Tradução de Moacir N. Vasconcelos. São Paulo: Livraria Martins/ Edusp, 1972. MARTIUS, C. F. P. von.; SPIX, Johann Baptist von. Viagem pelo Brasil: 1817-1820. Tradução de Lúcia Furquim Lahmeyer. Belo Horizonte: Itatiaia; São Paulo: Edusp, 1981. MAWE, John. Viagens ao interior do Brasil [1812]. Tradução de Selena Benevides Viana. Belo Horizonte: Itatiaia; São Paulo: Edusp, 1978. ORBIGNY, Alcide d’. Viagem pitoresca através do Brasil [1836]. Tradução de David Jardim. Belo Horizonte: Itatiaia; São Paulo: Edusp, 1976. PINK, Edmund. São Paulo de Edmund Pink. São Paulo: Bovespa, 2000. SAINT-HILAIRE, Auguste de. Viagem à província de São Paulo e resumos das viagens ao Brasil, Província Cisplatina e Missões do Paraguai (18191822). Tradução de Rubens Borba de Morais. São Paulo: Edusp; Martins, 1972.

${ }^{15}$ Afora os estrangeiros, dois paulistas e um baiano publicaram as memórias de juventude vivida na antiga capital paulista. AZEVEDO, Manuel Antônio Álvares de, 1831-1852. Cartas de Álvares de Azevedo. [São Paulo]: Academia Paulista de Letras, 1976. BARROS, Maria Paes de. No tempo de dantes [1 $1^{\mathrm{a}}$ ed.1946]. $2^{\mathrm{a}}$ ed. São Paulo: Paz e Terra, 1998. BUENO, Francisco de Assis Vieira. A cidade de São Paulo. Recordações evocadas de memória [1903]. São Paulo: Bib. Acad. Paul. de Letras, 1976. ${ }^{16}$ Os escritores mais conhecidos do público das histórias de São Paulo são ainda: SAMPAIO, Teodoro. São Paulo no século XIX e outros ciclos históricos. 2ª ed. Petrópolis: Vozes, 1978. MARTINS, Antônio Egydio. São Paulo antigo (1554 a 1910). São Paulo: F. Alves, 1911. BRUNO, Ernani Silva. História e tradições da cidade de São Paulo. Rio de Janeiro: José Olímpio, 1953.

${ }^{17}$ TAUNAY, Affonso de E. História colonial da cidade de São Paulo no século XIX. Vol. III [180122]. São Paulo: Dep. Cultura, [1956]. Idem. História da cidade de São Paulo sob o império. Vol. IV [1822-31]. São Paulo: Dep. Cultura, [1956]. Idem. História da cidade de São Paulo sob o Império. Vol. V [1831-42]. São Paulo: Publicação da Divisão do Arquivo Histórico, 1961. Idem. História da cidade de São Paulo sob o Império. Vol. VI [1842-54]. São Paulo: Dep. Patr. Hist., Div. Arq. Hist., 1977. Nas comemorações do $450^{\circ}$ aniversário da capital, Paula Porta coordenou uma história de São Paulo em três volumes, sobre economia e finanças do século XIX. Ler: NELSON, Nozoe. Vida econômica e finanças municipais da capital paulista na época imperial. In: PORTA, Paula (org.). História da cidade de São Paulo. Vol. 2, 1823-1889. São Paulo: Paz e Terra, 2004, p. 99-151. ${ }^{18}$ Comentaremos a obra no decorrer do artigo. RABELLO, Elizabeth Darwiche. Os comerciantes
} 
dos comerciantes na vida econômica e política paulista, pesquisa rica em informações e conclusões, mas que suscita muitas dúvidas. ${ }^{19}$

O viajante mais citado pelos historiadores da cidade foi Auguste de SaintHilaire que se hospedou em São Paulo durante sua pesquisa botânica em 1819, retornando em 1822. O naturalista contou-nos suas impressões sobre a capital e seu comércio. Em síntese, descreve uma cidade asseada, com clima agradável, mais movimentada que Vila Rica, com preços módicos, porém, distante do seu porto, exigindo assim uma caminhada estafante de dois dias. Para ele, essa posição geográfica comprometia seu crescimento. Observou, ainda, que "são vistas na cidade muitas lojas bem sortidas e bem arrumadas, em que se encontra uma variedade de mercadorias quase tão grande como a das existentes nas lojas do Rio de Janeiro". ${ }^{20}$

Figura 1. Rua São Bento em 1862. Sobrado da antiga Casa Sousa

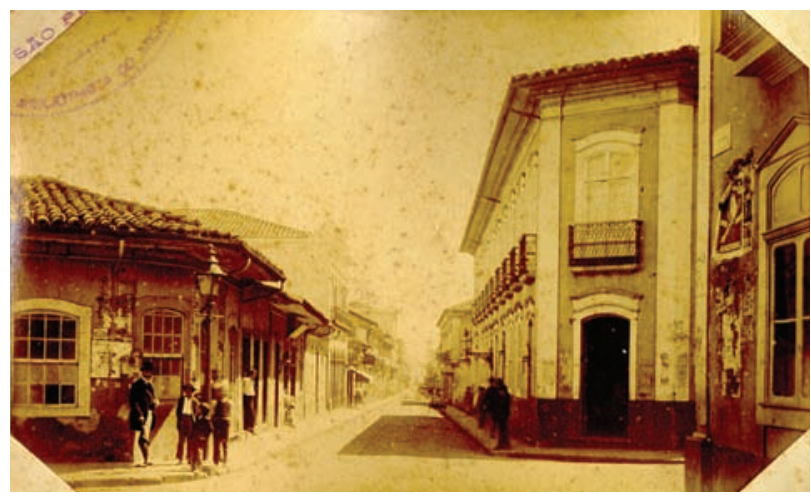

Álbum Militão (Militão Augusto de Azevedo). São Paulo: Arquivo do Estado de São Paulo, 2003. 1 CD.

As memórias do dr. Francisco de Assis Vieira Bueno sobre a cidade imperial, onde residiu nos anos trinta, têm sido igualmente recordadas pelos biógrafos de São Paulo. Segundo Vieira Bueno:

na sociedade paulistana na primeira metade do século XIX. Tese de livre docência, FCL-Unesp. Assis, 1988.

${ }^{19}$ Algumas teses sobre São Paulo optaram pela história vista por baixo e o comércio volante, a saber: DIAS, Maria Odila Leite da Silva. Quotidiano e poder em São Paulo no século XIX. São Paulo: Brasiliense, 1984. MOURA, Denise Aparecida Soares de. Sociedade movediça: economia, cultura e relações sociais em São Paulo, 1808-1850. São Paulo: Unesp, 2005.

${ }^{20}$ SAINT-HILAIRE, op. cit., p. 161. 
O comércio de retalho de fazendas secas, bebidas e mercearias, alimentado pelo consumo de uma população pobre de 15 a 20 mil habitantes, era diminuto. Lojas de fazendas de uso comum haveria, quando muito, umas vinte, com a singularidade de pertencerem quase todas a sujeitos que tinham apelidos esquisitos, em cuja invenção o povo era fértil e espirituoso, como Bom Fumo, Boas Noites, Maneco Entrecosto, Domingos Cai-Cai etc. De ferragens havia só uma na rua Direita, pertencente ao Maneco da Ferragem. De louça também havia somente um armazém, que por exceção pertencia a um brasileiro chamado Teco. Digo, por exceção, porque todos os donos de negócios eram portugueses. O sortimento desse armazém, situado em frente à rua do Colégio, hoje do Palácio, compunha-se de pratos e tigelas de pó de pedra, e dos grandes copos de vidro usados nas tavernas. De vinho havia igualmente um só, no largo da Sé, pertencente ao Chico Ilhéu, tipo grotesco de que depois terei ocasião de me ocupar. ${ }^{21}$

Consequentemente, os historiadores que difundem essas recordações reforçam a ideia de comércio e consumo irrisórios na cidade até a grande expansão cafeeira das últimas décadas do século XIX. Pretendemos, pois, com base em outras fontes, responder às questões: havia em São Paulo lojas com produtos quase tão variados como nas ruas da corte, segundo as considerações de SaintHilaire, ou a capital era ainda um espaço semirrural de comércio insignificante, conforme as lembranças de Francisco de Assis Vieira Bueno? Qual o nível de especialização desse comércio? Qual o perfil dos proprietários?

\section{Documentação}

Nesta seção faremos um balanço da documentação utilizada, suas possibilidades e limites, pois cremos que:

[t]out livre d'histoire digne de ce nom devrait comporter un chapitre, ou si l'on prefere, insere aux points tournants du dévelopment une suite de

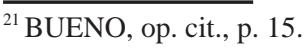


paragraphes qui s'intitulerait à peu prés: 'comment puis-je savoir ce que je vais dire?".22

Os estoques dos inventários post mortem de 1800 a 1850, as listas nominativas, os anúncios publicados em O Farol Paulistano, a relação de lojas da Décima Urbana, o registro e as atas do Senado da Câmara de São Paulo, a lista de comerciantes de Almanak administrativo, mercantil, e industrial da província de São Paulo para os anos de 1857 e 1858 compuseram a documentação primária da pesquisa. Além disso, reportar-nos-emos à literatura que tratou desse tema no século anterior.

O Farol Paulistano foi o primeiro periódico da província de São Paulo. O jornal circulou entre 1827 e 1833, era semanário e passou a bissemanário. O dr. José da Costa Carvalho era editor e proprietário, Antônio Mariano de Azevedo Marques, seu organizador. Esse jornal foi mantido por diversos anunciantes da província, especialmente pelos lojistas da cidade de São Paulo, e somente por esses anúncios constatamos que a vida comercial da capital dos anos vinte era bem mais diversificada que as Recordações evocadas de memória, de Francisco de Assis Vieira Bueno.

O Almanak administrativo, mercantil, e industrial da província de São Paulo para o anno de 1857, editado por Marques \& Irmãos, marcou o início das publicações especializadas em assuntos de comércio e indústria em São Paulo; esse almanaque foi editado por dois anos e seguiu o modelo da edição dos irmãos Laemmert do Rio de Janeiro. ${ }^{23}$ Recorda Ana Maria Camargo que, nos anos trinta, circularam folhinhas de ano novo pela capital com propaganda das principais casas de comércio, mas não restou nenhum exemplar delas nos arquivos. ${ }^{24}$

Os almanaques vieram a facilitar a seleção dos produtos pelo consumidor. Além dos anúncios comerciais veiculados também pelo jornal, eles propunham divulgar os dados gerais dos setores de serviços, comércio e indústria. Essas informações nos indicaram o percurso de alguns agentes mercantis, situaram

\footnotetext{
${ }^{22}$ BLOCH, Marc. Apologie pour l'histoire ou métier d'historien. $4^{\mathrm{a}}$ ed. Paris: A. Colin, 1961, p. 30. ${ }^{23}$ MARQUES \& Irmãos. Almanak administrativo, mercantil, e industrial da província de São Paulo para o anno de 1857. São Paulo: T. Marques, 1856. Idem, ano 1858. LAEMMERT, Eduardo \& Henrique. Almanak administrativo, mercantil e industrial do Rio de Janeiro. Rio de Janeiro: Laemmert, 1844.

${ }^{24}$ CAMARGO, Ana Maria de Almeida. Os primeiros almanaques de São Paulo. Introdução à edição fac-similar dos almanaques de 1857 e 1858. São Paulo: Impesp/Daesp, 1983.
} 
as lojas pelas várias ruas da cidade e indicaram a quantidade e variedade de estabelecimentos do comércio de meados do século XIX.

A Décima Urbana, ou Décima dos Rendimentos dos Prédios Urbanos, foi um dos impostos introduzidos após a vinda da família real, que tributava as propriedades para renda e as moradas do núcleo central das principais cidades da América portuguesa. "Foi imposto nas Villas da Marinha d'esta Província pelo Alvará de 23 de Junho de 1808, e n'esta Cidade, e Villas de serra acima por outro de 3 de Junho de 1809; a qual se cobra nas povoaçoens que tem de cem, casas para cima”. ${ }^{25}$

As informações coletadas nesses livros demonstram que o centro urbano paulista possuía número considerável de propriedades alugadas e lojas desde 1809. A parte central era composta por 34 ruas e 20 travessas, com 1.281 propriedades ( $80 \%$ térreas e $20 \%$ sobrados), sendo 149 casas de morada com suas lojas, perfazendo 185 lojas disponíveis das quais 70\% estavam alugadas, isto é, delineava-se a tendência a agrupar os imóveis para aluguel e o comércio nas ruas centrais, favorecendo assim o crescimento do mercado imobiliário nessa área. Os sobrados e as lojas concentravam-se nas ruas de São Bento, Direita, Santa Teresa e Largo da Sé.

O Senado da Câmara das vilas luso-brasileiras tinha por atribuições fiscalizar os ofícios mecânicos e as atividades comerciais. Cabia-lhe conceder licença para o exercício público do ofício em sua tenda aberta, ${ }^{26}$ e para o funcionamento de novas lojas; além disso, os pesos e medidas eram regularmente aferidos pelo almotacé. ${ }^{27}$ Alguns desses procedimentos foram anotados nas Actas e registros da Câmara de São Paulo. ${ }^{28}$

\footnotetext{
${ }^{25}$ MÜLLER, Daniel Pedro. Ensaio d'um quadro estatístico da provincia de São Paulo [1838]. São Paulo: Governo do Estado, 1978, p. 211. Sobre o tributo da propriedade urbana, ver: ARAÚJO, Maria Lucília Viveiros. O centro urbano de São Paulo no limiar do Oitocentos. Revista Histórica. Arquivo do Estado de São Paulo, São Paulo, n 5, p. 60-62, dez. 2001. O Arquivo do Estado de São Paulo possui dois livros de registro de arrecadação da Décima Urbana da capital referentes aos anos de 1809 (completo) e 1829 (incompleto).

${ }^{26} \mathrm{O}$ juiz e o escrivão do ofício avaliavam o candidato. Ler sobre esse procedimento em: FLEXOR, Maria Helena Ochi. Oficiais mecânicos da cidade de Salvador. Salvador: Prefeitura Municipal, 1974. BARROS, Daisy Ribeiro de Morais. Um século dos ofícios mecânicos na vila de São Paulo. Dissertação de mestrado, FFLCH, Universidade de São Paulo, 1982.

${ }^{27}$ Verificar os cargos da administração luso-brasileira em: SALGADO, Graça (org.). Fiscais e meirinhos: a administração no Brasil colonial. Rio de Janeiro: N. Fronteira, 1985.

${ }^{28}$ Registro geral da Câmara Municipal de São Paulo. São Paulo: A. Municipal de São Paulo; Piratininga, 1921/22. Actas da Camara Municipal de São Paulo. São Paulo: A. Municipal; Piratininga, 1921.
} 
Os inventários post mortem nos forneceram os dados sobre as mercadorias disponíveis nas lojas e armazéns da cidade na primeira metade do século XIX. ${ }^{29}$ Os avaliadores desses processos eram minuciosos quanto aos bens móveis dos falecidos. Dessa forma, suas descrições esclareceram-nos sobre as características dos produtos (material, cor, origem, adereços, medidas, embalagem) e seus preços. Localizamos 81 negociantes da capital com inventários, mas poucos mantinham ainda estoques em casa; o negociante de fazendas Manoel Alves Alvim, por exemplo, tivera loja na rua do Comércio, porém, na época do falecimento, já a havia transferido para o filho. Além disso, nem todo comerciante necessitava de "loja aberta" e os vendedores de semoventes e os contratadores não acumulavam gêneros mercantis. Consequentemente, restou-nos uma amostra de 28 negociantes com estoques, sendo dois inventários com lojas do mesmo casal. As lojas estavam localizadas na área central, região estratégica das vendas da capital para os compradores das vilas próximas e para a distribuição pelo interior. Não obstante as diferenças dos níveis de riqueza desses mercadores, como não havia ainda distinção entre atacadistas e varejistas, secos e molhados, optamos por analisar o conjunto das lojas e armazéns com o objetivo de identificar a oferta dos gêneros comerciais.

Utilizamos também as listas nominativas da capital para identificar ocupação, naturalidade, estado conjugal e endereço do comerciante. Porém, para avaliar o potencial de consumidores, recorremos à historiografia que estudou o perfil dessa população. Segundo M. Luiza Marcílio, em 1802, havia 24.311 habitantes; 25.486, em 1816; e 21.933 (24,2\% eram escravos), em 1836. A redução da população deveu-se ao desmembramento de Santo Amaro em 1832. ${ }^{30}$ Elizabeth Kuznesof pesquisou os fogos das freguesias centrais da capital: eram 568 fogos, em 1765; 1.069, em 1802; e 1.863, em $1836 .{ }^{31}$ Os fogos haviam crescido $88 \%$ na passagem do século XVIII para o XIX e $74 \%$ nas décadas

\footnotetext{
${ }^{29}$ Os inventários post mortem da capital do século XIX permanecem no Arquivo do Judiciário do Estado de São Paulo. Esses processos mudaram várias vezes de numeração, consequentemente eles devem ser procurados por nome das partes e ano. Ver a análise dos cabedais dos moradores da capital em: ARAÚJO, Maria Lucília Viveiros. Os caminhos da riqueza dos paulistanos na primeira metade do Oitocentos. São Paulo: Hucitec/Fapesp, 2006.

${ }^{30}$ MARCÍLIO, Maria Luiza. A cidade de São Paulo: povoamento e população, 1750 - 1850, com base nos registros paroquiais e nos recenseamentos antigos. Tradução da autora da tese de 1968 . São Paulo: Pioneira/Edusp, 1974, p. 98-99.

${ }^{31}$ KUZNESOF, Elizabeth Anne. Household economy and urban development. São Paulo, 1765 to 1836. Boulder, London: Westview Press, 1986, p. 97.
} 
seguintes, por conseguinte, teriam aumentado os consumidores da cidade. Além disso, entre 1800 e 1849, foram criadas 26 novas vilas na capitania/província de São Paulo. Muitas delas eram clientes potenciais dos negociantes paulistas. ${ }^{32}$ Enfim, todos os dados indicam um crescimento populacional e econômico de grande parte da província ao longo do século XIX. ${ }^{33}$

Quanto aos comerciantes, os recenseamentos sugerem que as taxas de crescimento desse grupo eram superiores ao crescimento populacional. Marcílio concluiu que o setor comercial cresceu três vezes na capital em sessenta anos: 102 chefes de fogos estavam ocupados no comércio em 1776; 217, em 1798; 401, em $1836 .{ }^{34}$ Elizabeth Rabello computou a naturalidade dos chefes de fogos das listas nominativas da capital de 1804 e 1825, e apurou que os negociantes da terra eram maioria: dos 136 negociantes de 1804, 62\% eram luso-brasileiros, $32 \%$ eram do Reino; em 1825, 45\% eram brasileiros, $35 \%$ eram portugueses e $5 \%$ provinham de outros países, num total de 176 chefes de fogos; os portugueses predominavam apenas nos negócios de fazenda seca. ${ }^{35}$ Isto é, Vieira Bueno não foi preciso nas informações da nacionalidade da maioria dos lojistas, pois, nos primeiros decênios do século XIX, o comerciante brasileiro era maioria; o setor comercial se expandia para aproveitar o surgimento de novas vilas e o aumento do consumo dos favorecidos pelas novas condições econômicas.

\section{Lojas, casas térreas e sobrados}

Na administração pombalina foi instituída a Junta do Comércio (1755) que "marca um momento crucial para a institucionalização da distinção entre o grosso trato e o varejo", ${ }^{36}$ em que eram representados apenas os homens de negócio estabelecidos com cabedal e crédito nas praças de Lisboa ou do Porto, ficando de fora os comissários volantes de fazendas para o Brasil. Reservou-se

\footnotetext{
${ }^{32}$ MARCÍLIO, Maria Luiza. Crescimento demográfico e evolução agrária paulista (1700-1836). São Paulo, 1974. Tese de livre docência. Faculdade de Filosofia, Letras e Ciências Humanas da Universidade de São Paulo. Publicada pela Hucitec, Edusp, 2000, p. 231.

${ }^{33}$ Conforme a análise demográfica da capitania e província de São Paulo em: LUNA, Francisco Vidal; KLEIN, Herbert S. Evolução da sociedade e economia escravista de São Paulo, de 1750 a 1850. São Paulo: Edusp, 2006.

${ }^{34}$ MARCÍLIO, A cidade ..., op. cit., p. 130-131.

${ }^{35}$ RABELLO, op. cit., p. 227.

${ }^{36}$ PEDREIRA, Jorge Miguel. Os negociantes de Lisboa na segunda metade do século XVIII; padrões de recrutamento e percursos sociais. Análise social, vol. XXVIII, n. 116/117, 1992, p. 407-440, p. 412.
} 
a denominação homens de negócios somente aos matriculados. Jorge Miguel Pedreira adverte que, apesar do aparente rigor nas matrículas de comerciantes por grosso, a realidade desse grupo era muito complexa: havia homens de negócio que possuíam lojas dirigidas pelos seus caixeiros, ou mercadores de loja aberta interessados no comércio a longa distância ou até na indústria, assim como se encontravam mercadores com fortunas apreciáveis e homens de negócio mais modestos. Em 1788, a Junta foi elevada à categoria de Tribunal Régio, com o título de Real Junta do Comércio, Agricultura, Fábricas e Navegação; em 1808, foi transferida para o Rio de Janeiro. A matrícula dos negociantes tornou-se obrigatória no Brasil em 1809, entretanto, poucos comerciantes paulistas se interessaram em formalizar matrícula na Real Junta; entre 1809 e 1850, eles representavam apenas $2 \%$ do total. ${ }^{37} \mathrm{O}$ coronel Francisco Antônio de Sousa, pai do tenente-coronel Francisco Inácio e irmão do brigadeiro Luís Antônio de Sousa, era o único negociante de São Paulo com biografia conhecida registrado na Junta.

Nosso trabalho não tratará preferencialmente dos negociantes de grosso. ${ }^{38}$ Buscamos aqui compreender uma parcela do comércio regional paulista, as vendas das lojas de secos e molhados, que, parafraseando Pedreira, podiam também proporcionar cabedais consideráveis. Assim como Mattoso, não procuramos diferenciá-los, visto que “[é] impossível, aliás, separar importadores-exportadores e varejistas, pois os primeiros também negociavam no varejo". ${ }^{39}$

Segundo Silva Bruno, constavam nas listas nominativas da capital de 1822:

(...) três boticários, quarenta e seis negociantes de "fazenda seca", quarenta e cinco de "molhados" e dois de ferragens. Com os seus estabelecimentos, em maioria, nas ruas do Rosário (onde havia vinte e três casas comerciais), Direita (com dezesseis), do Comércio (com vinte) e de São

\footnotetext{
${ }^{37}$ A relação dos matriculados foi publicada por PUNTSCHART, William. Negócios e negociantes paulistas: 1808-1822. Tese de doutorado, FFLCH, Universidade de São Paulo, 1998, p. 11; e por RABELLO, op. cit., p. 187. Não adotamos a interpretação de Rabello de que o reduzido número de paulistas dessa lista devia-se à falta de capital para requerer matrícula.

${ }^{38} \mathrm{O}$ trabalho de Fragoso optou pelos negociantes do Império marítimo português. FRAGOSO, João Luís Ribeiro. Homens de grossa aventura: acumulação e hierarquia na praça mercantil do Rio de Janeiro (1790-1830) [tese de 1990]. 2a ed. Rio de Janeiro: C. Brasileira, 1998.

${ }^{39}$ MATTOSO, op. cit., p. 494.
} 
Bento (com nove). Lojas de fazendas de uso comum haveria quando muito umas vinte. ${ }^{40}$

Tabela 1. Lista de negociantes com estoques

\begin{tabular}{|c|c|c|c|c|c|}
\hline \multicolumn{6}{|c|}{ Negociantes com lojas na capital, 1802 a 1850} \\
\hline Nome & Data & Endereço & Estoque rs & Libra $£$ & $\%$ Monte bruto \\
\hline João Jose Moreira, cap. & 1802 & São Bento & 2.843 .654 & 853 & $30,8 \%$ \\
\hline Rosa Maria do Rosario Pedrosa & 1803 & Rego de S.Francisco & 404.276 & 121 & $12,2 \%$ \\
\hline Antonio Jose Dias Coelho & 1806 & Rego de S.Francisco & 358.077 & 107 & $12,8 \%$ \\
\hline Antonio Rodrigues Salgado, guarda-mor & 1806 & Direita & 1.707 .745 & 512 & $16,7 \%$ \\
\hline Joaquina Angelica de Castro & 1806 & Rosário & 752.508 & 226 & $24,4 \%$ \\
\hline Antonio Alvares dos Reis capitão & 1810 & trav. São Bento & 439.465 & 131 & $9,9 \%$ \\
\hline Diogo Jose de Sousa, alferes & 1811 & Comércio & 5.844 .396 & 1.792 & $62,0 \%$ \\
\hline João de Almeida e Cunha & 1811 & ? & 566.131 & 174 & $21,1 \%$ \\
\hline Domingos Fernandes Lima, cap. & 1812 & Comércio & 2.697 .706 & 861 & $18,5 \%$ \\
\hline Gregorio Jose Soares, tenente & 1813 & Rosário & 449.675 & 162 & $38,7 \%$ \\
\hline Jose Pinto Tavares, cap. & 1815 & largo S. Efigênia & 1.832 .851 & 489 & $9,6 \%$ \\
\hline Antonio Martins da Silva & 1816 & pátio da Misericórdia & 820.691 & 195 & $20,2 \%$ \\
\hline Luis Antonio de Sousa, brig. & 1819 & Ouvidor & 10.787 .083 & 2.598 & $0,9 \%$ \\
\hline Gertrudes Maria da Costa & 1821 & beco Rosario & 109.720 & 24 & $2,5 \%$ \\
\hline Manoel Jose Vilaça, alferes & 1823 & Luz & 4.567.731 & 964 & $10,7 \%$ \\
\hline Manoela Jesuina de Jesus & 1827 & Comércio & 825.690 & 121 & $16,5 \%$ \\
\hline Antonio Joaquim Furquim Justino & 1828 & São Gonçalo & 144.580 & 19 & $6,7 \%$ \\
\hline João Jose Rodrigues, cap. & 1828 & Santa Teresa & 453.020 & 58 & $1,9 \%$ \\
\hline Manoel Rodrigues Jordão, brig. & 1828 & Direita & 875.472 & 113 & $0,3 \%$ \\
\hline Francisco Inacio de Sousa Queiros & 1831 & Direita & 2.096 .840 & 218 & $1,0 \%$ \\
\hline Francisco Gomes da Silva & 1832 & Rosario & 3.393.544 & 499 & $39,3 \%$ \\
\hline João Antonio Rosa & 1832 & Ouvidor & 7.666 .365 & 1.127 & $21,0 \%$ \\
\hline Jose Vicente Lisboa, sarg-mor & 1837 & Rosário & 370.290 & 59 & $9,9 \%$ \\
\hline Pedro Fernandes de Andrade, cap. & 1837 & Comércio & 7.044 .414 & 1.128 & $58,0 \%$ \\
\hline Jose Vaz da Cunha & 1840 & trav. Comércio & 1.115 .230 & 147 & $25,9 \%$ \\
\hline Antonio Jose Cardoso & 1842 & São Bento & 1.206 .960 & 152 & $13,9 \%$ \\
\hline João da Conceição Maldonado & 1842 & pátio S. Francisco & 638.470 & 81 & $5,2 \%$ \\
\hline Bernardo Francisco de Azevedo & 1843 & Rosário & 15.786 .677 & 1.763 & $23,0 \%$ \\
\hline Francisco Antonio de Miranda, cap. & 1844 & Luz & 644.650 & 69 & $3,1 \%$ \\
\hline Jose Antonio Gonçalvez & 1850 & Rosário & 1.998.191 & 215 & $18,4 \%$ \\
\hline
\end{tabular}

Fonte: inventários post mortem do Arquivo do Judiciário de São Paulo

Rabello calculou 332 pessoas envolvidas com o comércio, em 1825, 46 delas ocupadas nos negócios de fazendas secas, 10 de molhados, 230 executavam tarefas comerciais variadas, como compra e venda de gado, de ouro, de sal, de contratos etc., 45 declararam viver de agências (venda de produtos do trabalho caseiro), 17 exerciam atividades nas quitandas (gulodices) e 84 de vendas (estabelecimentos da cidade e estradas com refeições), além de cinco boticários. ${ }^{41}$ Cláudia M. G. Chaves analisou o comércio setecentista fixo em

\footnotetext{
${ }^{40}$ BRUNO, Ernani Silva. História e tradições da cidade de São Paulo. Vol. 1, Arraial de sertanistas (1554-1828). São Paulo: J. Olympio, 1954, p. 319.

${ }^{41}$ RABELLO, op. cit., tabela 6, p. 64; 145-147.
} 
Minas Gerais, atestando as dificuldades para se distinguir as especialidades dessas atividades, pois "à exceção das tavernas, estabelecimentos que comercializavam apenas bebidas, especialmente a aguardente, não temos definições exatas sobre as lojas e vendas". ${ }^{42}$

Localizamos 28 comerciantes inventariados com suas lojas em diversas ruas da capital, a saber: seis lojas na rua do Rosário e uma no beco do Rosário; três na rua do Comércio e uma na sua travessa; três na rua Direita; duas na rua São Bento e uma na sua travessa; nas ruas Ouvidor e Luz residiam dois em cada uma delas; e nas ruas Santa Teresa, São Gonçalo, pátios da Misericórdia, de São Francisco, rego de São Francisco e largo de Santa Ifigênia, habitavam os demais comerciantes; não encontramos o endereço de João de Almeida e Cunha; talvez morasse de aluguel ou na casa do sogro, o mercador Manoel Ferraz de Araújo. ${ }^{43}$

Esses negociantes constituíram lojas com estoques de diferentes valores e produtos. A maioria comercializava principalmente fazendas, por isso foram classificados nos recenseamentos como negociantes de fazendas secas, ou negociantes de fazendas secas do Rio de Janeiro. Estes últimos deviam ser comissários ou fregueses dos importadores instalados na corte. ${ }^{44}$ Segundo a instrução para o governo da capitania de Minas Gerais, redigida pelo desembargador José João Teixeira Coelho, em 1780, "por fazenda seca se entende o que se não come nem bebe, e serve para vestir, e por fazenda de molhados se entende os comestíveis, ferro, aço, pólvora e tudo o mais que se não veste". ${ }^{45}$

De acordo com nossas pesquisas, os negociantes residentes na capital forneciam créditos para 67 localidades e sete províncias, em contrapartida, contraíam dívidas em 13 localidades e duas províncias; os créditos dos negociantes provinham $90 \%$ da própria cidade e somente $7 \%$ da praça do Rio de Janeiro.

\footnotetext{
${ }^{42}$ CHAVES, Cláudia Maria das Graças. Perfeitos negociantes: mercadores das minas setecentistas. São Paulo: Annablume, 1999, p. 59.

${ }^{43}$ Tratamos dos objetos das casas de morada disponíveis nas lojas em: ARAÚJO, Maria Lucília Viveiros. Os interiores domésticos após a expansão da economia exportadora paulista. Anais do Museu Paulista, São Paulo, v. 12, p.129-160, jan-dez. 2004.

${ }^{44}$ RABELLO, op. cit. p. 92, apresentou uma grande lista de negociantes de fazendas do Rio de Janeiro. Entretanto, em cada recenseamento, o entrevistado podia aparecer em outra classificação, por exemplo, "vive de seu negócio", "negócio de fazenda", "vive das cobranças do negócio que teve de fazenda seca" etc.

${ }^{45}$ COELHO, José João Teixeira. Instrução para o governo da capitania de Minas Gerais. Revista do Instituto Histórico e Geográfico Brasileiro. Rio de Janeiro, tomo 15, n. 7, $3^{\text {a }}$ série, p. 257-460, $3^{\circ}$ trim. 1852, p. 405.
} 
Essas dívidas correspondiam às aquisições de fazendas secas e molhados dos atacadistas locais e da corte. ${ }^{46}$

\section{Fazendas secas e assemelhados}

Os comerciantes de fazendas secas conservavam produtos com diferentes valores, a saber: o brigadeiro Luís Antônio de Sousa, falecido em 1819, possuía loja própria e em sociedade; a loja principal ficava na sua casa de morada de sobrado na esquina da rua do Ouvidor com produtos variados avaliados em 10:787\$083 (dez contos, setecentos e oitenta e sete mil, oitenta e três réis); em Santos, nos sobrados da rua da Praia, mantinha peças de ferragens e muitos instrumentos de trabalho que valiam 14:274\$200; tinha ainda sociedade na loja de fazendas de Luís Assunção, da rua São Francisco (só consta o valor de 10:652\$050), e sociedade com João Antônio Rosa na botica da rua do Ouvidor. Ele foi o mais importante exportador de açúcar e importador de fazendas secas de São Paulo da passagem do século XVIII e início do século XIX. No entanto, sua casa vendia também as quinquilharias do estabelecimento comercial de Antônio Martins da Silva avaliado por $820 \$ 691$ (oitocentos e vinte mil, seiscentos e noventa e um réis), em $1816 .{ }^{47} \mathrm{O}$ brigadeiro armazenava grande quantidade de panos na rua do Ouvidor, entre elas: 928 côvados $(68 \mathrm{~cm})$ de baeta, 663 peças de ganga açucarada, ${ }^{48}$ e tinha também quatro varas $(1,10 \mathrm{~m})$ de paninho para pequenas vendas; além disso, essa loja comercializava especiarias, confecções, drogas, aviamentos, utensílios de cozinha, ferragens, objetos pessoais e higiene, papelaria e jogos.

Entre os negociantes de fazendas secas, o alferes Diogo José de Sousa destacou-se com 3:547\$ (três contos, quinhentos e quarenta e sete mil réis) em tecidos, correspondendo a $61 \%$ do seu estoque; seguem-no João de Almeida e Cunha com $356 \$ 730$ em fazendas valendo $63 \%$ do valor da loja; capitão Domingos Fernandes Lima (82\%); Antônio Martins da Silva (53\%); alferes Manoel

\footnotetext{
${ }^{46}$ Conforme dados de ARAÚJO, Os caminhos ..., op. cit., p. 121 e 124.

${ }^{47} \mathrm{O}$ brigadeiro (Amarante 1754 - SP 1819) começara a enriquecer com os negócios das minas de Cuiabá, passando, a seguir, para a comercialização e produção de açúcar; na época do falecimento, a maioria dos bens era representada por 15 engenhos, duas fazendas de gado e estoques de açúcar. Ele mantinha procuração com negociantes de Sorocaba, Santos, Iguape, Mato Grosso, Goiás, Rio de Janeiro, Minas Gerais, Lisboa, Porto e Amarante.

${ }^{48}$ Fazenda de algodão para confeccionar calças masculinas. DALGADO, Sebastião R. Glossário luso-asiático. Hamburg: Buske Verlag, 1982.
} 
José Vilaça (2:337\$, 61\%) e o brigadeiro Luís Antônio de Sousa (3:921\$, 36\%). Após a Independência, os comerciantes com maior porcentual de fazendas nos estoques foram: o capitão João José Rodrigues (80\%), brigadeiro José Rodrigues Jordão (367\$880, 35\%), coronel Francisco Inácio de Sousa (1:535\$, 63\%), Francisco Gomes da Silva (74\%), sargento-mor José Vicente Lisboa (182\$420, 49\%), capitão Pedro Fernandes de Andrade (5:206\$, 65\%), Bernardo Francisco de Azevedo (8.319\$, 53\%). O maior estoque de fazendas em libras esterlinas pertencia ao alferes Diogo José Sousa (£1.087), seguido do brigadeiro Luís Antônio (£944) e de Bernardo Francisco de Azevedo (£929). Somente Antônio Martins, José Vicente Lisboa e Diogo José de Sousa mantinham a loja anexa à morada de casas térreas, com fazendas vendidas por varas e em retalhos; os demais negociantes habitavam em morada de casas de sobrado, de dois ou mais lanços, formadas em paredes de pilão, cobertas de telhas, forradas e assoalhadas, com loja no térreo e seu quintal. ${ }^{49}$

Os tecidos encontrados em todas as lojas eram baetas, baetilha, baetão, belbutina, belbute, bombazina, bretanha, brim, casemira, cassa, cetim, chita, droguete, durante, fustão, ganga, holanda, linho, pano, paninho, sarja, serafina, seda, tafetá, veludo. Alguns deles eram classificados pela procedência, possivelmente para justificar seus valores. As chitas podiam ser inglesas, francesas ou da fábrica; a ganga era inglesa ou da Índia; o zuarte, da Índia; a sarja, de Málaga; o cetim, de Macau, do Porto ou francês. Nos primeiros anos vendiam-se panos da fábrica de Porto Alegre, nos anos quarenta apareceram diversas peças e varas de algodão americano.

O preço das fazendas variou muito, visto que dependia das especificações desse produto - fino, grosso, ordinário, mais largo -, da conservação e das cores, por exemplo, a baeta preta era mais cara que a baeta de cores. A baeta rosa ou azul foi comercializada por $\$ 570$ o côvado, a preta por $\$ 800$, em 1806 ; em 1850 , a baeta de cores custava $\$ 680$, a preta foi avaliada por $\$ 880$, em 1837 ; o

\footnotetext{
${ }^{49}$ A função comercial dos sobrados da cidade foi observada por Gilberto Freyre, mas esse autor centrou sua atenção nos hábitos urbanos da burguesia. FREYRE, Gilberto. Sobrados e mucambos: decadência do patriarchado rural no Brasil. São Paulo: Nacional, 1936. Sobre as opções de taxa de conversão dos mil-réis para libra esterlina no século XIX, ver: NELSON, Nozoe et al. Brasil: breves comentários sobre algumas séries referentes à taxa de câmbio. Boletim de História Demográfica, ano XI, n. 32, maio 2004.
} 
preço da baeta de cores aumentou aproximadamente $19 \%$, quer dizer, percentual inferior à desvalorização dos mil-réis no período. ${ }^{50}$

Essas casas vendiam peças de vestuário e acessórios em menor volume. $\mathrm{O}$ alferes Diogo José de Sousa mantinha $8 \%$ de seus estoques com esses produtos, entre outros: vestidos de cassa (1\$000), luvas de camurça $(\$ 400)$, coletes de baeta, cobertores ingleses de papa (2\$000). A casa do capitão José Pinto Tavares vendia chapéus Braga copa alta $(1 \$ 440)$ e copa baixa $((\$ 600)$, barretes de lã (\$350), gorros estreitos (\$120), colchas de algodão pintadas, lenços de seda e pares de tamancos $(\$ 240)$. A casa do brigadeiro Luís Antônio comercializava inclusive as redes de algodão (1\$920) e guarda-camas de algodão (\$480) produzidos pelas mulheres da cidade, conforme observou o viajante Gustavo Beyer, em 1813. ${ }^{51}$

Francisco Inácio de Sousa Queirós destinava 20\% do estoque para os gêneros confeccionados, entre outros: toalhas Guimarães adamascadas grandes (24\$000), toalha do Porto lavrada (4 $\$ 000)$, lençóis lisos de linho com fronha (2\$400), meias de linho. Bernardo Francisco de Azevedo mantinha 8\% desses produtos. Este comerciante possuía uma morada de casas térreas e dois sobrados, com seu barco, na rua do Rosário, fundos para a rua Porto Geral, onde se encontravam pares de meias de seda, cobertores espanhóis (4500), barretes de lã, lenços de seda nessa loja. Os estoques do brigadeiro Manoel Rodrigues Jordão (SP 1781 - SP 1827) eram proporcionalmente insignificantes na época do seu falecimento: restavam 368\$000 em fazendas secas, 173\$000 em drogas e 334\$000 em metais. Ele apresentou o segundo maior espólio de comerciantes; possuía 144 créditos na capital e 39 em diferentes vilas, mas o grosso dessas dívidas era de contas das sociedades com sítios e engenhos. O negociante do Rio de Janeiro, coronel Manoel Moreira Lírio, devia-lhe 2:892 contos de réis; as

\footnotetext{
${ }^{50}$ Os estudos nacionais de preços no século XIX basearam-se nas listas de compras de alimentos dos livros das Santas Casas de Misericórdias. Desconhecemos trabalhos equivalentes para São Paulo. Ler sobre o tema: LOBO, Eulália Maria L. et al. Evolução dos preços e do padrão de vida no Rio de Janeiro, 1820-1930 - resultados preliminares. Revista Brasileira de Economia, v. 25, $\mathrm{n}^{\circ}$ 4, p. 235-265, out./dez. 1971. MATTOSO, op. cit.; para Portugal: GODINHO, Vitorino Magalhães. Prix et monnaies au Portugal, 1750-1850. Paris: A. Colin, 1955. Taunay apontou as tendências de alta dos preços na fase de rush do ouro com a análise dos livros de mordomia do Mosteiro de São Bento. TAUNAY, Affonso de E. História da cidade de São Paulo no séc. XVIII. Vol. II (1765-1801). São Paulo: Dep. Cultura - Div. Arq. Hist., 1951, p. 178 e 180.

${ }^{51}$ BEYER, op. cit., p. 288.
} 
contas correntes no Rio de Janeiro permitiam-lhe o abastecimento de fazendas secas e o fornecimento de peles e bestas para a corte.

Tabela 2. Lista de preços dos estoques e variação

\begin{tabular}{|c|c|c|c|c|c|c|}
\hline Produto & Medida & Ano & Preço Rs & Ano & Preço Rs & Variação \\
\hline Açucareiro pó pedra & unidade & 1815 & 200 & 1837 & 140 & $-30 \%$ \\
\hline Alfinete & carta & 1811 & 110 & 1844 & 40 & $-64 \%$ \\
\hline Baeta cores & côvado & 1806 & 570 & 1850 & 680 & $19 \%$ \\
\hline Breu & libra & 1811 & 75 & 1844 & 50 & $-33 \%$ \\
\hline Brocha de sapateiro & unidade & 1803 & 72 & 1843 & 32 & $-56 \%$ \\
\hline Cafeteira de louça & unidade & 1815 & 340 & 1837 & 200 & $-41 \%$ \\
\hline Chita padrões & côvado & 1806 & 430 & 1843 & 200 & $-53 \%$ \\
\hline Colchetes & grosa & 1815 & 480 & 1843 & 600 & $25 \%$ \\
\hline Cravo-da-índia & libra & 1803 & 3.000 & 1843 & 640 & $-79 \%$ \\
\hline Droguete rei & côvado & 1806 & 240 & 1832 & 240 & $0 \%$ \\
\hline Durante & côvado & 1806 & 320 & 1843 & 320 & $0 \%$ \\
\hline Enxofre & libra & 1806 & 120 & 1843 & 60 & $-50 \%$ \\
\hline Erva-doce & libra & 1819 & 240 & 1843 & 200 & $-17 \%$ \\
\hline Livro de Santa Bárbara & unidade & 1813 & 16 & 1837 & 10 & $-38 \%$ \\
\hline Marmelada & caixeta & 1806 & 240 & 1840 & 120 & $-50 \%$ \\
\hline Meias de seda & par & 1811 & 2.000 & 1850 & 2.000 & $0 \%$ \\
\hline Miçanga & maço & 1803 & 640 & 1837 & 800 & $25 \%$ \\
\hline Pedra-ume & libra & 1806 & 120 & 1823 & 100 & $-17 \%$ \\
\hline Pimenta-da-índia & libra & 1806 & 320 & 1843 & 160 & $-50 \%$ \\
\hline Pregos pau-a-pique & milheiro & 1806 & 4.000 & 1843 & 2.000 & $-50 \%$ \\
\hline Pregos ripares & milheiro & 1806 & 1.000 & 1843 & 680 & $-32 \%$ \\
\hline Salsa parilha & libra & 1811 & 1.008 & 1843 & 900 & $-11 \%$ \\
\hline Tafetá cores & côvado & 1806 & 400 & 1837 & 200 & $-50 \%$ \\
\hline Tesoura pequena & unidade & 1806 & 100 & 1843 & 62 & $-38 \%$ \\
\hline Cobre & libra & 1802 & 240 & 1850 & 240 & $0 \%$ \\
\hline Ouro & oitava & 1802 & 1.400 & 1850 & 2.400 & $71 \%$ \\
\hline Prata & oitava & 1802 & 100 & 1850 & 200 & $100 \%$ \\
\hline Libra esterlina* & & 1808 & 3.333 & 1850 & 9.277 & $178 \%$ \\
\hline
\end{tabular}

Fonte: estoques dos inventários do AJESP

*Vide Nozoe. Op. cit.

A clientela dos médios negociantes era principalmente da capital, mas nas vilas tributárias (Bragança, Campinas, Curitiba, Moji-Mirim, Porto Feliz, Itu etc.) havia varejistas associados aos atacadistas da capital. Além disso, alguns negociantes instalaram lojas nas novas regiões agrícolas para aproveitar o rápido crescimento delas; por exemplo, José Pinto Tavares, em Moji-Mirim, Bernardo Francisco de Azevedo, em Campinas, Manuel de Oliveira Cardoso e Francisco José de Sampaio Peixoto, em Curitiba. 
A maioria das lojas de fazendas oferecia meias de seda para senhora, de algodão ou linho para homens e crianças, lenços, chapéus, cortes para vestidos, mas poucos vestidos, estes deviam ser confeccionados pelas costureiras da cidade. Conforme as memórias de Maria Paes de Barros, "[o]s vestidos de chita eram costurados em casa. Os de passeio, de cassa, eram costurados por uma costureira". ${ }^{52}$ Essas mesmas casas forneciam os aviamentos para as costuras, tais como: varas ou peças de fitas, cadarços, elásticos, rendas, galões; grosas (12 dúzias) ou dúzias de botões, dedais, colchetes, miçangas; maços, macinhos, cartas ou milheiros de alfinetes, agulhas, linha, granadas, miçangas, cadarços; meadas de linhas, lãs; tesouras.

A ourivesaria foi uma importante atividade artesanal desde o período colonial. As listas nominativas indicam diversos ourives na capital - eram oito em 1804 e 15 em $1825^{53}$ - contudo nenhum deles abriu inventário. ${ }^{54}$ Até o aparecimento das joalherias, os comerciante de fazendas e produtos de armarinhos ofereciam joias, possivelmente de confecção local e outras importadas.

Diogo José de Sousa, português, negociante de fazendas do Rio de Janeiro, residia na rua do Comércio, onde faleceu, sem filhos, em 1811. Ele era um típico comerciante, pois mantinha mais de 70\% dos bens em estoques e dívidas ativas. Seu armarinho era dos mais sortidos da cidade, equivalia a $9 \%$ do valor da loja; ali a clientela podia adquirir pares de botões de punhos de ouro (2.742\$), vara de fita (\$81), libra de alfinetes, dúzia de dedal (\$120), vara de renda da França (\$320) etc., ou as joias das filhas e esposas, como contas de ouro, par de brincos de vidro, par de brincos de ouro (10\$450), cordão de ouro, anel de ouro e topázio.

Localizamos apenas dois negociantes de fazendas penhorados em dívidas: João José Moreira tinha vários credores no Rio de Janeiro, devia a Manoel Caetano 4:020\$, ao seu irmão, 1:995 contos de réis, a maior parte dos bens (dívidas ativas e estoques) não era suficiente para cobrir os débitos; e Antônio José Cardoso, com 85\% dos bens em créditos, devia a Antônio Ferreira e Sousa \& Companhia 2:696\$ e a José Luís Cardoso 6:947\$, mais que seu monte

\footnotetext{
${ }^{52}$ BARROS, op. cit., p. 50.

${ }^{53}$ RABELLO, Elizabeth D. A cidade e sua estrutura profissional: 1804-1825. In: COSTA, Iraci del Nero da (org.). Brasil: história econômica e demográfica. São Paulo: IPE/USP, 1986, p. 223-244. ${ }^{54}$ Localizamos, em um inventário, pagamentos ao ourives José Wenceslau. ARAÚJO. Os interiores domésticos ..., op. cit., p. 145.
} 
bruto, provocando assim a falência do espólio. As contas das outras casas eram equilibradas.

No final dos anos cinquenta, havia 10 lojas de joias e ourivesaria na capital; Supplicy, Prest, Schroeder, Valein, Masseran eram nomes novos nessa atividade, imigrantes com habilidades artesanais. ${ }^{55}$ Lojas de fazendas eram 50, sendo que Antônio Moreira da Cruz, Bernardo Quartim, Domingos de Paiva Azevedo, Francisco José Azevedo, Manoel Antônio Bitancourt deviam ser sucessores de antigos negociantes de fazendas da capital - não reconhecemos os sobrenomes dos demais, alguns deles podiam ser genros de antigos negociantes. ${ }^{56} \mathrm{O}$ único estrangeiro era Theodor Wille \& Cia., atacadista de fazendas secas da rua Direita. Wille havia desembarcado em Santos nos anos trinta, onde abriu uma empresa de importação e exportação em 1844; em seguida, expandiu os negócios para Hamburgo, São Paulo e Rio de Janeiro. ${ }^{57}$

\section{Molhados e mantimentos}

As ocupações ligadas aos gêneros molhados envolviam menores investimentos. Em média, esses negociantes apresentaram monte bruto menor do que o grupo das fazendas secas. Havia muitos deles nas antigas listas nominativas, contudo poucos abriram inventários.

Joaquina Angélica de Castro declarou viver de quitandas. Parda, de pai incógnito, casou aos trinta anos já com os negócios estabilizados. Júnia Furtado e Renato Venâncio destacaram o compadrio como estratégia para a ascensão social principalmente para as mulheres comerciantes, ${ }^{58}$ pode ter sido este 0

\footnotetext{
${ }^{55}$ Bivar pesquisou os imigrantes franceses em São Paulo e o ourives Luís Supplicy. BIVAR, Vanessa Santos. Vivre à St. Paul: os imigrantes franceses na São Paulo oitocentista. Tese de doutorado, FFLCH, Universidade de São Paulo, 2008.

${ }^{56}$ Nazzari e Metcalf desenvolveram a ideia de sucessão das terras preferencialmente pelo genro e o costume da matrilinearidade e matrilocalidade nos casamentos paulistas. Identificamos diversos negociantes que transferiram seus negócios para os genros, coincidindo com a hipótese dessas brasilianistas. NAZZARI, Muriel. Dotes paulistas: composição e transformações (1600-1870). Revista Brasileira de História. n 9, v. 17, p. 87-100, set. 1988, fev. 1989; METCALF, Alida C. Fathers and sons: the politics of inheritance in a colonial Brazilian township. Hispanic American Historical Review. no 3, v. 66, aug. 1986, p. 455-484.

${ }^{57}$ MORAES, Maria Luiza de Paiva Melo. A atuação da firma Theodor Wille \& Cia. no mercado cafeeiro do Brasil, 1844-1918. Tese de doutorado, FFLCH, Universidade de São Paulo, 1988.

${ }^{58}$ FURTADO, Júnia; VENÂNCIO, Renato. Comerciantes, tratantes e mascates. In: DEL PRIORE, Mary. Revisão do paraíso: os brasileiros e o Estado em 500 anos de história. Rio Janeiro: Campus, 2000, p. 95-113.
} 
caminho do sucesso dessa comerciante que recebeu significativo legado do padrinho branco. Sua quitanda na rua do Rosário continha as mesmas mercadorias das lojas ou armazéns de molhados, a saber: louça ordinária do Porto; talheres, urinóis, chapéus, cordas, cera, fumo, pipas, copos, pentes, peneiras e potes da terra; coco da Bahia, manteiga, aguardente, azeitona, azeite de peixe, sal, caixetas de marmelada, bacalhau, vinagre, azeite e vinho; santos, bilros de renda, panos de algodão, chita, bombas de beber, rosários de cocos, totalizando 61 diferentes peças avaliadas em 753\$000. Sua venda diferia das lojas de molhados na qualidade dos produtos. Ela vendia preferencialmente produtos classificados de "ordinários” e da terra, ou seja, produtos mais acessíveis para os funcionários menos graduados. Na mesma rua do Rosário, Gertrudes Maria da Costa, proprietária de várias casas em São Paulo e de um sobrado em Santos, especializara-se também na venda de bebidas e alimentos, inclusive queijos. $\mathrm{O}$ barril de genebra era encontrado na Luz, nas casas do capitão Francisco Antônio de Miranda e as botijas dessa bebida nas casas de Vaz da Cunha. ${ }^{59}$

Por outro lado, o capitão Pedro Fernandes de Andrade, viúvo, natural das Ilhas, amealhou a maior fortuna desse grupo. Ele devia possuir o maior depósito de bebida da sua época. $\mathrm{O}$ armazém fornecia barris, cartolas e garrafas de vinho da companhia (\$300), Madeira (\$320), moscatel (\$320), engarrafado (\$300), branco (\$320), além de garrafas de cerveja (\$160), licor de fora (\$240), manteiga, azeite, chocolate, sal, entre outros. O comerciante abastecia a casa do presidente Bernardo José Pinto Gavião Peixoto. Além dessa atividade, Pedro Fernandes possuía loja de fazendas secas no mesmo sobrado da rua do Comércio, avaliada por 6 contos de réis, quer dizer, as fazendas representavam $65 \%$ do valor dos gêneros comercializados por ele. $\mathrm{O}$ capitão tinha mais de 5 contos de réis em dívidas das contas correntes com José Antônio Fernandes e João Gonçalves Pereira, ambos do Rio de Janeiro, mas seus ativos eram suficientes para saldá-las.

Constavam 84 armazéns de molhados e gêneros da terra no almanaque para 1857, com 17 sobrenomes estrangeiros (Joint, Bresser, Springer, Heidrichs,

\footnotetext{
${ }^{59}$ Os alimentos (sal, arroz, farinha) eram comercializados em alqueires (correspondente a 13,8 litros e peso variável); arrobas, $14,7 \mathrm{~kg}$ (bacalhau, macarrão, arenque, toucinho, farinha, café, açúcar). Os molhados ficavam em barris ou cartolas (azeite, 79,7 litros, azeitona, vinho, 84,8 litros, vinagre, peixe); garrafas de 1,706 litros (vinhos); óleo, chocolate, manteiga e temperos eram vendidos em libras $(0,459 \mathrm{~kg})$; sal e azeite podiam ser medidos também em ternos $(1 / 3 \mathrm{de}$ garrafa); a cachaça e a aguardente, em canadas (1,41 litros). Cf. tabelas de conversão da metrologia de LISANTI FILHO, Luis. Negócios coloniais (uma correspondência comercial do século XVIII). $1^{\circ}$ vol. Brasília: M. Fazenda; São Paulo: Visão, 1973.
} 
Greiner, Franck, Rostausher, Hamelung, Fuchs, Schier, Loskiell, Schaeffer, Klein, Cunera, Christ, Rose). Eram os imigrantes das colônias alemãs que haviam conseguido recursos para instalar-se nas principais ruas da capital; conforme Sílvia Siriani, “indivíduos que prosperaram em seus ofícios, detentores de técnicas consideradas superadas pelo ponto de vista europeu, porém inovadoras numa economia em processo de mecanização como a nacional" ${ }^{60}$ O Laemmert relacionou 93 armazéns de vinho e comércio de molhados por atacado com apenas seis nomes estrangeiros no Rio de Janeiro; três armazéns especializados em azeite, além de centenas de lojas de molhados e outras centenas de lojas de secos e molhados.

\section{Livros e papéis}

A maioria das lojas paulistas mantinha um pequeno estoque de artigos de papelaria como compassos, resma ou mãos de papéis, penas de lápis, lápis, tinteiros, penas de canetas, cadernos. Em cinco delas localizamos livros de santos, cartilhas, tabuadas e cartas de baralho, especialmente na "livraria" de Dias Coelho que fornecia leituras para o diversificado público da região: clérigos, profissionais liberais, funcionários do governo, estudantes.

Antônio José Dias Coelho (1748 - 1806), natural de Santiago de Chamoim, arcebispado de Braga, morador na chácara do rego de São Francisco, com casas de três lanços, quintais e pastos, declarou-se negociante de fazendas secas. Ele havia residido em Lisboa por dez anos, quando serviu ao clérigo, posteriormente sagrado arcebispo dioclesiano da capitania de São Paulo. Dias Coelho partiu para São Paulo, onde estabeleceu loja e casou-se em 1781. Para o suprimento da "casa", mantinha contas-correntes com vários negociantes do Rio de Janeiro; sua rede de amizades e de negócios era formada de clérigos e irmãos leigos das ordens religiosas paulistas.

Essa loja foi inventariada duas vezes: primeiramente, pelo falecimento de Rosa Maria do Rosário Pedrosa em 1803; a seguir, pela morte de Dias Coelho em 1806 . No primeiro inventário, o casal apresentou $63 \%$ do valor dos estoques em 844 volumes de livros de 119 títulos; no segundo, havia 446 volumes de 164 títulos. Era a loja com maior variedade de livros de sua época e, ainda assim, vendia produtos de armarinho, de higiene, especiarias, ferragens e instrumentos

\footnotetext{
${ }^{60}$ SIRIANI, Sílvia Cristina Lambert. Uma São Paulo alemã: vida quotidiana dos imigrantes germânicos na região da capital (1827-1889). São Paulo: Daesp/Imesp, 2003, p. 145.
} 
de trabalho. Sua especialização em livros e cartas de baralhos devia-se à exclusividade que lhe foi concedida pelo Senado da Câmara por diversos anos, ${ }^{61}$ pois "na sociedade de Antigo Regime, a participação nos mercados depende em grande parte dos privilégios”. ${ }^{62}$ Após sua morte, e com as mudanças advindas da transferência da corte para o Brasil, outros lojistas puderam comercializar esses produtos.

Cremos que apenas parte dos livros comercializados ficava nos estoques dos comerciantes, aqueles exemplares de venda mais rápida, pois no inventário de Dias Coelho havia muitas encomendas de livros de clérigos paulistas. Os maiores devedores do casal eram os reverendos Luís Gonzaga Rodrigues, José Moreira da Rocha, João Damaceno Maciel, Manoel Ferraz, Antônio Antunes, Antônio Feijó, além do padre Tristão Ferreira de Faria. Ele era fornecedor do comerciante Manoel Joaquim Amaral Gurgel, de Piracicaba. Em seu estoque localizamos 85 Livro de Santa Bárbara, o mais popular livro religioso da América Portuguesa, e diversificada literatura, principalmente publicações de meados do século XVIII, da reforma pombalina, e traduções de obras do início desse século, tais como as Aventuras de Telemaco, de Francisco da Salignac da Motha Fenelon, falecido em 1715.

\section{Tabela 3: Lista de livros de Antônio José Dias Coelho}

\begin{tabular}{llccr}
\hline \multicolumn{1}{c}{ Autor } & \multicolumn{1}{c}{ Obra } & Ano & Volumes & \multicolumn{1}{c}{ Real } \\
\hline Almeida Teodoro & Tesouro de paciencia nas ... & 1779 & 1 & 320 \\
Antonio Felix Mendes & Gramaticas & 1759 & 4 & 1.280 \\
Antonio Pereira de Figueiredo & Elogios dos reis de Portugal & 1785 & 2 & 1.280 \\
Cândido Lusitano & Artes poeticas de Horacio & 1758 & 4 & 2.800 \\
Fortunato dos Santos Neto & Horas lusitanas & 1766 & 4 & 2.240 \\
Francisco S. M. Fenelon & Aventuras de Telemaco & 1785 & 3 & 1.920 \\
Jean-François Marmontel & Belizario & 1785 & 2 & 1.440 \\
João Pedro do Vale & Tolo por arte e sábio por jeito & 1794 & 1 & 640 \\
Joseph de Laporte & Viajante universal & 1799 & 29 & 12.800 \\
Tristão Barbosa de Carvalho & Peregrinação de um cristão & 1744 & 3 & 1.800 \\
\hline & & & & \\
\hline
\end{tabular}

Fonte: Inventários post mortem de 1803 e 1806, Arquivo do Judiciário do Estado de São Paulo.

\footnotetext{
${ }^{61}$ Registro geral da Câmara Municipal de São Paulo, 1803-08, volume XIII. São Paulo: A. Municipal de São Paulo; Piratininga, 1921, p. 185.

${ }^{62}$ MADUREIRA, op. cit., p. 9.
} 
Identificamos, também, livros nos inventários de outros cinco negociantes, a saber: Antônio Álvares dos Reis, de 1810, 18 obras; Domingos Fernandes Lima de 1812, 15 livros; Gregório José Soares de 1813, 31 exemplares; José Pinto Tavares de 1815, 21; brig. Luís Antônio de Sousa, 45 exemplares de 1819, 1823. A maioria dos livros versava sobre temas religiosos, dicionários, gramáticas e poesias, em português, espanhol, francês e latim.

Após a abertura comercial, especialmente com o fim da censura prévia dos livros em 1821, as casas da capital anunciavam, em O Farol Paulistano, diversos títulos de leitura leiga. Por exemplo, a loja de fazendas da rua do Rosário, casa $\mathrm{n}^{\circ} 13$, vendia uma porção de livros Medicina curativa, em quatro volumes, do médico da corte José Maria Bomtempo; a loja da rua do Comércio $\mathrm{n}^{\mathrm{o}} 3$ anunciava especialmente livros de direito e matemática, tais como: Guia dos juízes de paz; Guia das câmaras municipais do Brasil, provavelmente de Antônio Diogo Feijó; Demonstrações da necessidade de abolição do celibato clerical, de Feijó; Diálogo constitucional brasiliense, José Paulo de Figueirôa Nabuco de Araújo, de 1827; Constituição do Império, de 1824; Compêndio de história dos EUA; Os elementos de Euclides; Compêndios de direito público, de Emmerich de Vattel; Cours de mathématiques, de Etiènne Bézout. Tomaz de Molina e Gabriel Henriques Pessoa ofereciam Princípios de direito nacional, compilados por José Maria Avellar Brotero; e na rua Direita ${ }^{\circ}$ 8, Mapa das garantias do cidadão brasileiro, além de livros franceses.

Havia 14 mercadores e lojas de livros no Rio de Janeiro, quatro franceses. Esses imigrantes instalaram-se na corte e passaram a dedicar-se ao comércio livreiro com distribuição para as outras províncias. ${ }^{63}$ Pierre Plancher-Seignol, editor do Jornal do Comércio, vendia livros na loja de Joaquim Lazaeta, na rua do Rosário no 19, em São Paulo. Os livros anunciados em 1829 eram Coleção de leis do Império do Brasil, Guia da conversação, Código penal militar, Código mercantil da França, Frutas do Brasil, Heloísa e Abeillard. O distribuidor paulista informava ainda que receberia encomendas de outras obras.

\footnotetext{
${ }^{63}$ Sobre livros e livreiros no Rio de Janeiro oitocentista, ver: ALGRANTI, Leila Mezan. Livros de devoção, atos de censura: ensaios de história do livro e da leitura na América portuguesa (1750-1821). São Paulo: Hucitec/Fapesp, 2004. MOREL, Marco. As transformações dos espaços públicos: imprensa, atores políticos e sociabilidades na cidade imperial (1820-1840). São Paulo: Hucitec, 2005. SILVA, Maria Beatriz Nizza da. O comércio de livros de Portugal para o Brasil e a censura. Revista do Inst. Histórico e Geográfico Brasileiro. ano 164, nº 419, p. 195-211, abril/ jun. 2003.
} 
Os almanaques de 1857 e 1858 relacionaram somente dois livreiros na capital, Bernardino José Dias Torres de Oliveira, rua da Imperatriz e José Fernandes de Sousa, largo do Colégio.

\section{Figura 2. Retrato de Francisco Inácio de Sousa Queirós}

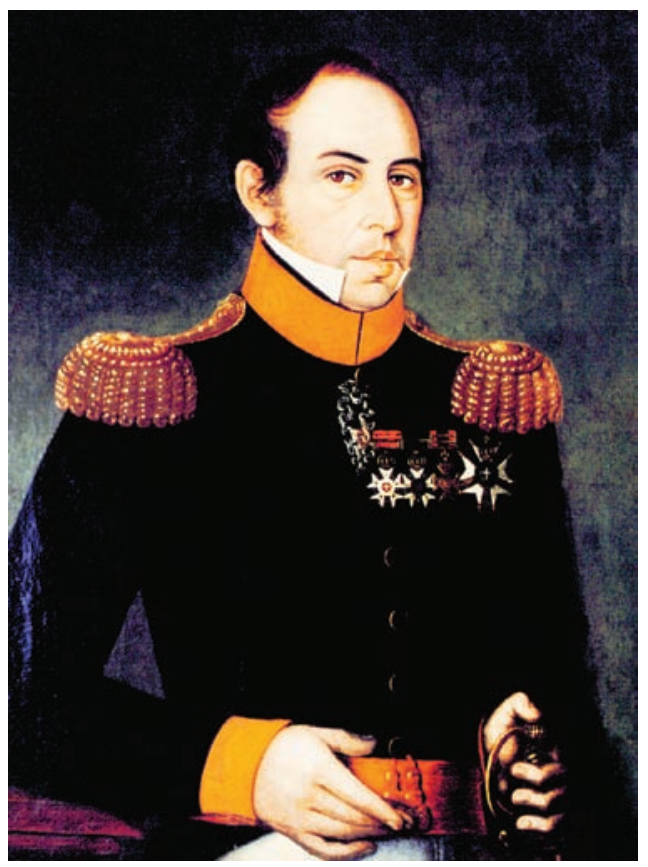

Autoria não identificada. Coronel Francisco Inácio de Sousa Queirós, s.d. Óleo sobre tela. Acervo do Museu Paulista.

Além dos livros para venda dos comerciantes aqui citados, identificamos livros de "uso pessoal" nas casas de onze mercadores que não tinham duas obras com o mesmo título, isto é, $21 \%$ dos 81 inventários do setor comercial revelaram posse de livros. Francisco Inácio de Sousa Queirós, ${ }^{64}$ com loja na rua Direita, herdada do pai, deixou uma biblioteca com 89 títulos de temas variados:

\footnotetext{
${ }^{64}$ Francisco Inácio de Sousa Queirós (SP 1789 - Porto 1830) era filho do negociante Francisco Antônio de Sousa, sobrinho e genro do brigadeiro Luís Antônio. Ele havia herdado a loja e os engenhos do pai e do sogro, possuía cinco engenhos e dois sítios ao falecer, além de outras 19 propriedades. A família residia numa luxuosa chácara na rua São João Batista, posteriormente arrendada para Francisco da Silva Prado.
} 
poesia, romance, filosofia, direito, história, teologia, gramática; Francisco José de Sampaio Peixoto, advogado, natural do Porto, contratador e negociante de tropas, foi outro grande leitor: sua biblioteca continha 79 títulos em português, espanhol e francês. ${ }^{65}$ A maioria das residências conservava livros de gramática, aritmética e retórica e dois títulos de práticas comerciais, Perfeito contador e Secretário português. ${ }^{66}$ Numa pesquisa sobre práticas de leitura no Brasil colonial, Luiz Carlos Villalta computou 14,5\% dos inventários no Rio de Janeiro e $20 \%$ em Diamantina, de 1750 a 1821, com listas de livros, ou seja, podemos considerar o nível de circulação de livros entre os comerciantes de São Paulo equivalente a esses centros urbanos. ${ }^{67}$ Por esse quesito e pelas contas em partilhas dobradas anexadas a alguns inventários post mortem, não compartilhamos da opinião de Rabello de que “(...) os comerciantes paulistanos deveriam ter pouco conhecimento relativo a sua profissão ou mesmo conhecimentos ligados a uma cultura geral”. ${ }^{6}$

\section{Drogas e boticas}

O comércio das drogas em São Paulo não passou pelo controle de distribuição como os livros e as cartas, ao contrário, o sueco Gustavo Beyer atestou que se vendiam drogas em qualquer venda e eram manipuladas sem qualquer restrição. ${ }^{69}$ Em 1811, os principais negociantes da capital assinavam uma declaração justificando essa liberalidade, criada em 1737, em benefício do bem público, porque não havia na capitania mais que quatro boticas, nem farmacêuticos e cirurgiões, logo "suprem esta grande falta os mercadores para os venderem, e os curiosos para os manipularem pelos sertões e vilas, pois é

\footnotetext{
${ }^{65}$ Sobre leitores no Rio de Janeiro, ver: ABREU, Márcia. Quem lia no Rio de Janeiro? In: CONGRESSO BRASILEIRO DE COMUNICAÇÃO, 24, 2001, Campo Grande, Mato Grosso do Sul. Campo Grande: Intercom. Sobre livros em São Paulo ver: DEAECTO, Marisa Midore. No império das letras: circulação e consumo de livros na São Paulo oitocentista. São Paulo, 2005; e a lista dos livros de José da Costa Carvalho em: ARAÚJO. Os caminhos ..., p. 171-178.

${ }^{66}$ FREIRE, Francisco José. O secretário português compendiosamente instruído no modo de escrever cartas. $2^{\mathrm{a}}$ ed. Lisboa: Oficina de Miguel Rodrigues, 1746. OLIVEIRA, Jose Monteiro. Perfeito contador, arithmetico portuguez. Lisboa: F. L. Ameno, 1754.

${ }^{67}$ VILLALTA, Luiz Carlos. Bibliotecas privadas e práticas de leitura no Brasil colonial.

Disponível em: < http://www.caminhosdoromance.iel.unicamp.br/estudos/ensaios/bibliotecas-br. pdf $>$. Acesso em 28/08/2008.

${ }^{68}$ RABELLO, op. cit., p. 211.

${ }^{69}$ BEYER, G., op. cit., p. 275.
} 
melhor isto, que morrerem à míngua sem recursos". ${ }^{70}$ Nenhum boticário assinou essa declaração.

Localizamos dois boticários na capital com inventário, Dionísio Ereopagita da Mota, nascido em São Paulo, solteiro, falecido em 1827, morador das casas com mirante e quatro janelas na rua Direita, filho do boticário Vicente Pires da Mota, irmão do cirurgião-mor Manoel Antônio Pires da Mota e tio do reverendo Vicente Pires da Mota. ${ }^{71}$ Sua botica foi leiloada antes do processo de inventário. O outro, o lisboeta João Antônio Rosa era casado com Margarida Maria da Conceição, filha natural do brigadeiro Luís Antônio; em sociedade com o sogro, ele havia conseguido formar uma grande botica na rua do Ouvidor, avaliada no inventário de 1832 , por $7.666 \$$, que foi herdada pelo genro, Manoel Rodrigues da Fonseca Rosa. Além dos produtos que todos vendiam - a exemplo de pedra-pome, pedra-ume, salsaparrilha, alfazema, noz-moscada -, sua casa armazenava centenas de outras substâncias, principalmente aquelas indicadas para digestão e vomitórios. Destacamos entre outras: raspa de veado, sal de amoníaco, raiz de genciana, galha, ópio, éter sulfúrico, mercúrio, resina de batata, vomitório de Le Roy, semente de linho, bálsamo de Riga. As drogas foram avaliadas em libras, umas poucas em medidas, onças (28,6 gramas), e arrobas (enxofre, salitre, breu, tamarindos, erva-doce, aguarrás, semente de linho, alvaiade, zarcão, maná, sal de Glauber).

Não obstante a liberalidade da venda de droga, a botica do Rosa manteve-se ativa por muitos anos; em 1827, ele anunciou em O Farol a inauguração da filial na rua do Comércio $\mathrm{n}^{\circ}$ 6, gerenciada pelo seu caixeiro; Lúcio Manoel Felix dos Santos informava, no mesmo jornal, que aguardava a distinta freguesia na sua botica de fronte à capela de Santo Antoninho. Até a publicação dos primeiros almanaques de São Paulo para os anos de 1857 e 1858, a farmácia do Rosa permanecia na rua do Ouvidor, próxima dos estabelecimentos de Joaquim Pires Garcia, na rua do Imperador, de Luiz Maria da Paixão e o da viúva de Loandro, ambos na rua de São Bento. Somente em 1858, Gustavo Gravenhorst e Schaumann assinaram contrato de sociedade para estabelecer uma botica com maquinário alemão. Schaumann batizou-a de Botica ao Veado d'Ouro. ${ }^{72}$

\footnotetext{
${ }^{70}$ Registro geral da Câmara Municipal de São Paulo, 1808-13, volume XIV. São Paulo: A. Municipal de São Paulo; Piratininga, 1922, p.345.

${ }^{71}$ Dr. Vicente Pires da Mota foi vice-presidente e presidente da província de São Paulo.

${ }^{72}$ SIRIANI, op. cit., p. 123. O Rio de Janeiro contava com 18 armazéns de drogas, medicamentos e produtos químicos e farmacêuticos, 45 lojas de drogas, sete nomes estrangeiros (Almanak Laemmert).
} 


\section{Louças, ferragens e construções}

As louças e os objetos da sala de jantar eram encontrados em quase todas as lojas. José Vaz da Cunha, da travessa da rua do Comércio, mantinha 21\% do valor de seu armazém de secos e molhados nesses produtos Ele oferecia principalmente o serviço completo de louça branca, a saber: canecas $(\$ 100)$, tigelas (\$100), xícaras (\$50). Ao lado, na rua Direita, encontravam-se saleiro de louça da Índia (\$160), frasco de chá de louça da Índia (\$320), pratos de louça de Macau (\$148), na loja de José Pinto Tavares. A loja do tenente Gregório José Soares vendia formas de fazer colheres de estanho; possivelmente os talheres de metal fossem produzidos na região na fase anterior à liberação do comércio. Nos anos trinta, vários negociantes anunciavam louças finas francesas. Em 1857 e 1858, louças e vidros podiam ser encontrados em cinco lojas de proprietários com nomes da tradição paulista, a saber: duas delas na rua do Comércio, duas outras na rua São Bento, a outra ficava na rua da Quitanda.

As ferragens e assemelhados eram avaliados em libras (cera, pólvora, cobre, arame, estanho, ferro), milheiro (tachas, pregos, palitos, espoletas); a oitava - 3,58 gramas - media ouro e prata. Pregos, dobradiças, cravos, formões, fechaduras, ferraduras, ferramentas, instrumentos de pedreiro e sapateiro podiam ser adquiridos na loja do alferes Manoel José Vilaça, ${ }^{73}$ na rua da Luz ou com o ferrador Floriano Antônio Rodrigues, na rua Jogo da Bola. Contudo, a mais completa casa de ferragens pertenceu a Lourenço José Correia de Guimarães, falecido em 1857, empresa instalada na rua do Comércio, filial na rua Direita, com estoque avaliado em $14.300 \$$, sendo $4.000 \$$ em ferramentas.

Conforme o almanaque para o ano de 1857, havia então 18 casas especializadas em ferragens na capital, como segue: seis na rua do Comércio, seis na rua Direita, três no Piques, duas na rua Alegre, uma na rua São Bento; nenhum lojista possuía sobrenome estrangeiro. A edição Laemmert desse ano informava haver 19 armazéns de ferros, aço, cobre e 98 lojas de ferragens no Rio de Janeiro com apenas três nomes estrangeiros.

\footnotetext{
${ }^{73}$ Manoel José Vilaça (Braga 1761 - São Paulo 1823) chegou jovem ao Rio de Janeiro. Primeiramente assistiu ao tio em Goiás, depois serviu como caixeiro ao comerciante José Gomes em São Paulo, por fim abriu loja própria. Possuía 510 credores nas seis províncias do sul do país, especialmente em Camanducaia, Minas Gerais, um terço dos credores era de Bragança, em São Paulo. A viúva manteve a loja de fazendas por vários anos.
} 
Os instrumentos dos ofícios eram igualmente encontrados em todas as lojas, a saber: peles (camurça, pelúcia, carneiro, bovino, cordovão, porco, cotia, veado e o marroquim), fios, linhas, trinchetes, cravadores, dedais, facas, banquetas, fivelas, brochas, calcanhares para sapateiros; martelos, serras, enxós, picão, pregos para carpinteiros e pedreiros, além de portas, janelas, vidros para as casas, tesouras e navalhas para os barbeiros; arreios, estribos, fivelas para seleiros. O material de construção mais pesado, como telhas, tijolos, fornos, caldeirões era vendido diretamente por seus produtores nas chácaras dos bairros. Por exemplo, o brigadeiro Manoel Rodrigues Jordão fabricava e vendia esses materiais no sítio do Ipiranga e Francisco Antônio Baruel no sítio Morrinhos, em Santana. Em meados do século XIX, teve início a grande transformação da técnica construtiva paulista, os tijolos substituem a taipa de pilão ou de mão e generalizou-se o uso das telhas. ${ }^{74}$ Nessa época os fabricantes de tijolos e de telhas eram Francisco Taques Alvim (Campo Redondo), neto do negociante de fazendas secas Manoel Alves Alvim; Francisco Antônio Baruel (Barra Funda), filho de homônimo; Joaquim Rodrigues Goulart (Freguesia do Ó) e Joaquim José Ferreira (largo do Arouche).

As mudanças ocorridas com a liberação do comércio externo da América portuguesa após 1808 e com a Independência são mais contundentes em $O$ Farol Paulistano. Esse jornal anunciava mercadorias de diferentes procedências vendidas na capital. Gabriel Henriques Pessoa, com loja na rua do Comércio com rua do Rosário, divulgava mensalmente nova lista de produtos, tais como: livros, cadeiras americanas, louças e chapéus franceses, sapatos de senhora, espelhos, fazendas da Índia e da América do Norte, papel almaço, genebra em frasqueiras, caldeiras, alambiques etc.; Aguiar Viúva e Filhos Cia., antiga casa de João Xavier da Costa Aguiar, de Santos, anunciava grande estoque de farinha da Filadélfia e drogas disponível em Santos ou em casa de Gabriel H. Passos na capital; B. Dillon divulgava relógios e moda francesa, Claudio Legoussat, pães franceses; o relojoeiro Kiehl distribuía e consertava maquinário francês, inglês e alemão; Guilherme Kraueter vendia piano forte de Londres, chapéus ingleses, trastes elegantes de Mahagony, todos chegados pelo bergatim Alexandre; por outro lado, Luís Antônio Payão (rua da Quitanda), Antônio Justiniano de Sousa e Gabriel H. Pessoa (rua do Rosário) continuavam a oferecer os tradicionais vinhos do Porto e de Lisboa, aguardente e bacalhau do reino.

\footnotetext{
${ }^{74}$ Essas mudanças arquitetônicas foram analisadas por, LEMOS, Carlos Alberto Cerqueira. Casa paulista. História das moradias anteriores ao ecletismo trazido pelo café. São Paulo: Edusp, 1999.
} 
O setor comercial do Rio de Janeiro era superior ao paulista, mesmo se considerarmos o contingente populacional maior da corte. A cidade do Rio de Janeiro contava, em 1799, com 134 lojas de varejo, 334 tavernas, 35 estancos de tabacos, 28 boticas, dois livreiros, para 43.376 habitantes. ${ }^{75}$ Em meados do século XIX, encontravam-se no Rio de Janeiro armazéns e lojas especializados em todos os produtos, tais como: tintas e vernizes, mármores, rapé, perfumes, quinquilharia, flores naturais, objetos de escritório, rendas, fantasias, consignação de comprar e vender escravos. Como em São Paulo, havia poucos nomes ingleses, franceses, alemães ou italianos entre os negociantes daquela praça, exceto entre os 44 proprietários de armazéns e lojas de modas e fazendas francesas, de seda, em cassa e morim, contando somente 13 proprietários com nomes "ibéricos", dos seis armazéns de gêneros norte-americanos; dois nomes apenas - Maxwell Jr., Vallinho \& C. e Filgueiras \& Sands - eram sociedades de nomes portugueses e ingleses. Esses dados indicam que, ainda que os produtos comercializados viessem da Europa ou Estados Unidos em avançado processo de industrialização, os nomes dos comerciantes permaneciam luso-brasileiros. Além disso, restava ainda uma parcela do mercado para os produtos da terra, pois identificamos 16 armazéns de pano de algodão e mantas de Minas Gerais, uma dezena de armazéns de louça do país, louça de barro e vidrada da terra, e armazéns de aguardente da terra. ${ }^{76}$ Essa comercialização de produtos regionais deve ter favorecido a implantação das primeiras indústrias no Rio de Janeiro na segunda metade do século XIX, conforme tese de Maria Bárbara Levy:

O processo dominante de transição industrial no Rio de Janeiro foi a acumulação do capital comercial que se encaminhou para a indústria de transformação, a partir de um conhecimento profundo do mercado consumidor, do acesso aos mecanismos de crédito e da utilização de matérias-primas procedentes dos centros com os quais comerciavam. ${ }^{77}$

A especialização das casas comerciais em São Paulo recebeu grande impulso a partir da segunda metade do século XIX, com a construção das ferrovias, o

\footnotetext{
${ }^{75}$ MATHIAS, Herculano Gomes. Comércio, 173 anos de desenvolvimento: história da Associação Comercial do Rio de Janeiro, (1820-1993). Rio de Janeiro: Expressão e Cultura, 1993, p. 12. SILVA, Joaquim Norberto de Souza e. Investigações sobre os recenseamentos da população geral do Império, e Resumo histórico dos inquéritos censitários realizados no Brasil. São Paulo: IPE, 1986, p. 97. ${ }^{76}$ Dados do Almanak Laemmert, op. cit.

${ }^{77}$ LEVY, Maria Bárbara. A indústria do Rio de Janeiro através de suas sociedades anônimas. Rio
} 
crescimento do mercado consumidor da capital e da província. Associados ao fornecimento regular dos produtos importados, esses novos estabelecimentos comercializavam preferencialmente: "Perfumarias francesas. Chá da Índia. Couro e sapatos ingleses e italianos. Chapéus Stetson, ingleses. Renda de Bruxelas. Camisas francesas Bertholet. (...)" ${ }^{78}$ No entanto, a maioria das lojas da capital permaneceu por longo tempo com nomes "nacionais", conforme nossa análise dos almanaques dos fins dos anos cinquenta e as conclusões de Marisa Midori Deaecto; de acordo com essa autora, dos 39 fundadores da primeira associação de auxílio mútuo dos negociantes paulistas, em 1884, somente oito deles eram estrangeiros recém-instalados na capital. ${ }^{79}$ Mattoso descreveu processo similar na Bahia:

No novo esquema que se estabeleceu nos anos 1830, os negociantes estrangeiros, sobretudo ingleses, não assumiram o monopólio português. Limitaram-se a operações de importação e exportação no próprio porto de Salvador, deixando aos luso-brasileiros um amplo espaço de operações comerciais em diferentes setores. ${ }^{80}$

Na lista de 79 proprietários e capitalistas do almanaque para 1857 há somente um alemão, Jacob Milchels. Os demais eram nomes de antigas famílias paulistas. Muitos descendentes de mercadores de fazendas secas aparecem, nessa lista, envolvidos em negócios ligados ao setor exportador e financeiro, tais como: Amador, Silvério, Manoel Rodrigues Jordão e Rafael de Araújo Ribeiro, respectivamente filhos e genro de Manoel Rodrigues Jordão; Vicente e Francisco Antônio de Sousa Queirós, filhos do brigadeiro Luís Antônio de Sousa; Francisco José de Azevedo, administrador dos Sousa Queirós; Antônio, Joaquim e Martinho da Silva Prado, filhos dos irmãos Silva Prado; Joaquim José dos Santos, Antônio Rodrigues Vilares e Francisca Victória Mendes da Silva, filhos de Joaquim José dos Santos; Francisco Garcia Ferreira, filho de Francisco Ferreira Garcia; Joaquim Lopes Guimarães, genro de Francisco Pinto Ferraz; assim como o grupo enriquecido no comércio de animais, Matheus, Gabriel

de Janeiro: Editora UFRJ; Secretaria Municipal de Cultura do Rio de Janeiro, 1994, p. 282.

${ }^{78}$ Crônica-memória de Jorge Americano, apud BARBUY, op. cit., p. 91.

${ }^{79}$ MIDORI, Marisa. Comércio e vida urbana na cidade de São Paulo (1889-1930). São Paulo: Senac, 2002, p. 97.

${ }^{80}$ MATTOSO, op. cit., p. 493. 
Cantinho, o barão de Antonina e o ex-boticário Lúcio Manoel Felix. Enfim, todas essas informações sugerem que as atividades comerciais haviam possibilitado o enriquecimento de muitas famílias na capital paulista na passagem do século XVIII e primeira metade do século XIX, e elas continuavam a favorecer a ascensão econômica de novos elementos, inclusive imigrantes. A oferta de produtos do exterior tendia a crescer, mas os distribuidores eram da terra.

\section{Considerações finais}

Levando-se em conta a pequena população da cidade e província de São Paulo, a expansão da escravidão nas áreas exportadoras, a forte atração que o comércio do Rio de Janeiro exercia sobre a região Sul, parece-nos que a estratégia dos negociantes paulistas de envolver-se em todos os ramos de negócios foi eficiente para aquele tempo, porquanto as lojas com todos os gêneros mercantis asseguravam uma freguesia constante. Localizamos várias lojas vendendo livros, cravo-da-Índia, louças, pregos, banheiras, pianos, perfumes, misturados ao tradicional negócio de fazenda seca. Aliás, essa antiga prática comercial foi renovada pelos supermercados com imenso sucesso no século XX.

As tendências de especialização das atividades comerciais chegaram com atraso a São Paulo, as técnicas e os espaços de construção começaram a alterar-se somente na segunda metade do século XIX, quando a vida comercial iniciava sua separação da vida doméstica. Essas mudanças e os recém-adquiridos hábitos de consumo acabaram favorecendo a renovação, inicialmente, das lojas de artigos de luxo nos últimos anos desse século. Além disso, outros reflexos da revolução industrial europeia foram sentidos nas longínquas terras de Piratininga, pois os preços dos gêneros mercantis mantiveram-se ou sofreram desvalorização por várias décadas.

Cremos que Saint-Hilaire foi um observador minucioso quando comparou a movimentação comercial do que vira na corte com as casas da pequena capital. Ele reparou que São Paulo era um depósito de produtos importados com comerciantes que revendiam produtos similares aos oferecidos no Rio de Janeiro. Em São Paulo e na corte imperial, os tecidos eram ingleses e franceses, as ferramentas alemãs, mas seus distribuidores eram ainda Alves, Brito, Carvalho, Ferreira, Leite, Neves, Silva, Teixeira etc. Os negociantes dos países produtores não formavam um grupo expressivo nessas cidades. As lojas paulistas permaneceram com estoques variados até aproximadamente os anos 
sessenta, quando começaram a surgir lojas especializadas em certos produtos, especialmente aqueles de luxo, com nomes e vitrines para exposição.

Enfim, nosso trabalho pretendeu analisar os estabelecimentos, as mercadorias e os proprietários da primeira metade do século XIX, além de suscitar um diálogo com a historiografia que tratou do comércio oitocentista. Relembramos que o tema faz parte de uma história de longa duração, iniciada no século XVIII, ou antes, caracterizada por Sérgio Buarque de Holanda como processo de mercantilização da economia paulista. ${ }^{81}$

\section{Referências bibliográficas}

ALGRANTI,LeilaMezan.Livros de devoção, atos de censura: ensaios dehistória dolivro e da leitura naAmérica portuguesa (1750-1821). São Paulo: Hucitec/Fapesp, 2004.

ARAÚJO, Maria Lucília Viveiros. O centro urbano de São Paulo no limiar do Oitocentos. Revista Histórica. São Paulo: Arquivo do Estado de São Paulo, n 5, dez. 2001, p.60-62.

ARAÚJO, Maria Lucília Viveiros. Os caminhos da riqueza dos paulistanos na primeira metade do Oitocentos. São Paulo: Hucitec/Fapesp, 2006.

ARAÚJO, Maria Lucília Viveiros. Os interiores domésticos após a expansão da economia exportadora paulista. Anais do Museu Paulista. São Paulo, v. 12, jan-dez. 2004, p.129-160.

ARRUDA, José Jobson de A. Uma colônia entre dois impérios: a abertura dos portos brasileiros 1800-1808. Bauru, São Paulo: C. J. Cortesão/ Edusc, 2008.

AZEVEDO, Manuel Antônio Álvares de (1831-1852). Cartas de Álvares de Azevedo. São Paulo: Academia Paulista de Letras, 1976.

BARBUY, Heloisa. A cidade-exposição: comércio e cosmopolitismo em São Paulo, 1860-1914. São Paulo: Edusp, 2006.

BARROS, Daisy Ribeiro de Morais. Um século dos ofícios mecânicos na vila de São Paulo. Dissertação de mestrado, Faculdade de Filosofia, Letras e Ciências Humanas da Universidade de São Paulo, 1982.

BARROS, Maria Paes de. No tempo de dantes [1 ${ }^{\mathrm{a}}$ ed. 1946]. $2^{\mathrm{a}}$ ed. São Paulo: Paz e Terra, 1998.

BEYER, Gustavo. Ligeiras notas de viagem do Rio de Janeiro à capitania de $\mathrm{S}$. Paulo, no Brasil, no verão de 1813... Tradução de Alfredo Löfgren. Revista do Instituto Hist. Geog. de S. Paulo. São Paulo, vol. XII, 1970, p. 275-311.

\footnotetext{
${ }^{81}$ Sérgio Buarque de Holanda, São Paulo. In: HOLANDA, Sérgio Buarque de (dir.) O Brasil monárquico. $6^{\mathrm{a}}$ ed. Rio de Janeiro: Bertrand, 1995, p. 415-472.
} 
BIVAR, Vanessa Santos. Vivre à St. Paul: os imigrantes franceses na São Paulo oitocentista. Tese de doutorado, FFLCH, Universidade de São Paulo.

BLAJ, Ilana. Agricultores e comerciantes em São Paulo nos inícios do século XVIII: o processo de sedimentação da elite paulistana. Revista Brasileira de História. São Paulo, v. 18, n. 36, 1998, p. 281-296.

BLOCH, Marc L. B. BLOCH, Marc. Apologie pour l'histoire ou métier d'historien. $4^{\mathrm{a}}$ ed. Paris: A. Colin, 1961

BORREGO, Maria Aparecida de Menezes. A teia mercantil: negócios e poderes em São Paulo colonial (1711-1765). Tese de doutorado, Faculdade de Filosofia, Letras e Ciências Humanas, Universidade de São Paulo, 2006.

BRAUDEL, Fernand. Civilisation matérielle et capitalisme: XV-XVIII siècle. $4^{\mathrm{a}}$ ed. Paris: A. Colin, 1979.

BRUNO, Ernani Silva. História e tradições da cidade de São Paulo. Rio de Janeiro: José Olímpio, 1953-4. 3 v.

BUENO, Francisco de Assis Vieira. A cidade de São Paulo. Recordações evocadas de memória [1 $1^{\mathrm{a}}$ ed. 1903]. São Paulo: Bib. Acad. Paul. de Letras, 1976.

CAMARGO, Ana Maria de Almeida. Os primeiros almanaques de São Paulo. Introdução à edição fac-similar dos almanaques de 1857 e 1858. São Paulo: Impesp/Daesp, 1983.

CHAVES, Cláudia Maria das Graças. Perfeitos negociantes: mercadores das minas setecentistas. São Paulo: Annablume, 1999.

COELHO, José João Teixeira. Instrução para o governo da capitania de Minas Gerais. Revista do Instituto Histórico e Geográfico Brasileiro. Tomo 15, n. 7, $3^{\mathrm{a}}$ série, $3^{\circ}$ trim., 1852 , p. 257-460.

CORNETTE, Joël. La révolution des objets. Le Paris des inventaires après décès (XVII-XVIII siècles). Revue d'histoire moderne et contemporaine. jul./set. 1989, p. 483-485.

COSTA, Iraci del Nero da (org.) Brasil: história econômica e demográfica. São Paulo: IPE/USP, 1986.

D'ALINCOURT, Luiz. Memória sobre a viagem do porto de Santos à cidade de Cuiabá [1830]. São Paulo: Martins, 1953.

DALGADO, Sebastião R. Glossário luso-asiático. Hamburg: Buske Verlag, 1982.

DEAECTO, Marisa Midore. No império das letras: circulação e consumo de livros na São Paulo oitocentista. São Paulo, 2005.

DEAECTO, Marisa Midori. Comércio e vida urbana na cidade de São Paulo (18891930). São Paulo: Senac, 2002.

DEL PRIORE, Mary. Revisão do paraíso: os brasileiros e o Estado em 500 anos de história. Rio de Janeiro: Campus, 2000. 
DIAS, Maria Odila Leite da Silva. Quotidiano e poder em São Paulo no século XIX. São Paulo: Brasiliense, 1984.

FLEXOR, Maria Helena Ochi. Oficiais mecânicos da cidade de Salvador. Salvador: Prefeitura Municipal, 1974.

FRAGOSO, João Luís Ribeiro. Homens de grossa aventura: acumulação e hierarquia na praça mercantil do Rio de Janeiro (1790-1830). Rio de Janeiro: A. Nacional, 1992.

FREIRE, Francisco Jose. O secretário português compendiosamente instruído no modo de escrever cartas. $2^{\mathrm{a}}$ ed. Lisboa: Oficina de Miguel Rodrigues, 1746.

FREYRE, Gilberto. Sobrados e mucambos: decadência do patriarchado rural no Brasil. São Paulo: Nacional, 1936.

GODINHO, Vitorino Magalhães. Prix et monnaies au Portugal, 1750-1850. Paris: A. Colin, 1955.

HOBSBAWM, Eric. J. Industry and empire: an economic history of Britain since 1750. London: Weidenfeld \& Nicolson, 1968.

HOLANDA, Sérgio Buarque de (dir.) O Brasil monárquico. São Paulo: Difel, 1971.

HOMEM, Maria Cecília N. O palacete paulistano e outras formas urbanas de morar da elite cafeeira. São Paulo: M. Fontes, 1996.

KIDDER, Daniel P. Reminiscências de viagens e permanências no Brasil [1842]. Tradução de Moacir N. Vasconcelos. São Paulo: Livraria Martins/ Edusp, 1972.

KUZNESOF, Elizabeth Anne. Household economy and urban development São Paulo, 1765 to 1836. Boulder, London: Westview Press, 1986.

LAEMMERT, Eduardo \& Henrique. Almanak administrativo, mercantil e industrial do Rio de Janeiro. Rio de Janeiro: Laemmert, 1844 e 1857.

LEMOS, Carlos Alberto Cerqueira. Casa paulista. História das moradias anteriores ao ecletismo trazido pelo café. São Paulo: Edusp, 1999.

LEVY, Maria Bárbara. A indústria do Rio de Janeiro através de suas sociedades anônimas. Rio de Janeiro: Editora UFRJ/Secretaria Municipal de Cultura do Rio de Janeiro, 1994.

LISANTI FILHO, Luis. Negócios coloniais (uma correspondência comercial do século XVIII). Brasília: M. Fazenda; São Paulo: Visão, 1973.

LOBO, Eulália Maria L. et all. Evolução dos preços e do padrão de vida no Rio de Janeiro, 1820-1930 - resultados preliminares. Revista Brasileira de Economia. v. $25, \mathrm{n}^{\circ} 4$, out./dez. 1971 , p. $235-265$.

LOBO, Eulália Maria L. Fontes para a história do comércio do Rio de Janeiro. América Latina en la historia económica. n 9, enero/jun. 1998, p. 65-75.

LUNA, Francisco Vidal; KLEIN, Herbert S. Evolução da sociedade e economia escravista de São Paulo, de 1750 a 1850. São Paulo: Edusp, 2006. 
MADUREIRA, Nuno Luís. Mercado e privilégios. A indústria portuguesa entre 1750 e 1834. Lisboa: Estampa, 1997.

MARCÍLIO, Maria Luiza. A cidade de São Paulo: povoamento e população, 1750 1850, com base nos registros paroquiais e nos recenseamentos antigos. Tradução da autora da tese de 1968. São Paulo: Pioneira; Edusp, 1974.

MARCÍLIO, Maria Luiza. Crescimento demográfico e evolução agrária paulista (1700-1836). São Paulo, 1974. Tese de livre docência, Faculdade de Filosofia, Letras e Ciências Humanas da Universidade de São Paulo. Publicada pela Hucitec, Edusp, 2000.

MARQUES \& Irmãos. Almanak administrativo, mercantil, e industrial da província de São Paulo para o anno de 1858. São Paulo: T. Marques, 1857.

MARQUES \& Irmãos. Almanak administrativo, mercantil, e industrial da província de São Paulo para o anno de 1857. São Paulo: T. Marques, 1856.

MARTINS, Antônio Egydio. São Paulo antigo (1554 a 1910). São Paulo: Francisco Alves, [1911].

MARTIUS, C. F. P. von.; SPIX, Johann Baptist Von. Viagem pelo Brasil: 18171820. Tradução de Lúcia Furquim Lahmeyer. Belo Horizonte: Itatiaia; São Paulo: Edusp, 1981.

MATHIAS, Herculano Gomes. Comércio, 173 anos de desenvolvimento: história da Associação Comercial do Rio de Janeiro (1820-1993). Rio de Janeiro: Expressão e Cultura, 1993.

MATTOSO, Katia M. de Queirós. A cidade do Salvador e seu mercado no século XIX. São Paulo: Hucitec; Salvador: S.M.E.C., 1978.

MAWE, John. Viagens ao interior do Brasil [1812]. Tradução de Selena Benevides Viana. Belo Horizonte: Itatiaia; São Paulo: Edusp, 1978.

METCALF, Alida C. Fathers and sons: The politics of inheritance in a colonial Brazilian township. Hispanic American Historical Review n ${ }^{\circ} 66,1986$, p. 455-484.

MORAES, Maria Luiza de Paiva Melo. A atuação da firma Theodor Wille \& Cia. no mercado cafeeiro do Brasil, 1844-1918. Tese de doutorado, Faculdade de Filosofia, Letras e Ciências Humanas, Universidade de São Paulo, 1988.

MOREL, Marco. As transformações dos espaços públicos: imprensa, atores políticos e sociabilidades na cidade imperial (1820-1840). São Paulo: Hucitec, 2005.

MOURA, Denise Aparecida Soares de. Sociedade movediça: economia, cultura e relações sociais em São Paulo, 1808-1850. São Paulo: Unesp, 2005.

MÜLLER, Daniel Pedro. Ensaio d'um quadro estatístico da provincia de São Paulo [1838]. São Paulo: Governo do Estado, 1978.

NAZZARI, Muriel. Disapearance of the dowry: women, families, and social change in São Paulo, Brazil (1600-1900). Stanford: Stanford University Press, 1991.

NAZZARI, Muriel. Dotes paulistas: composição e transformações (1600-1870). Re- 
vista Brasileira de História. São Paulo, v. 9, nº 17, set. 1988, fev. 1989, p. 87-100. NELSON, Nozoe et al. Brasil: breves comentários sobre algumas séries referentes à taxa de câmbio. Boletim de História Demográfica, ano XI, n. 32, maio 2004.

OLIVEIRA, Jose Monteiro. Perfeito contador, arithmetico portuguez. Lisboa: F. L. Ameno, 1754.

OLIVEIRA, Maria Luiza Ferreira de. Entre a casa e o armazém: relações sociais e experiência de urbanização: São Paulo, 1850-1900. São Paulo: Alameda, 2005.

ORBIGNY, Alcide d’. Viagem pitoresca através do Brasil [1836]. Tradução de David Jardim. Belo Horizonte: Itatiaia; São Paulo: Edusp, 1976.

PEDREIRA, Jorge Miguel. Os negociantes de Lisboa na segunda metade do século XVIII; padrões de recrutamento e percursos sociais. Análise social, vol. XXVIII, n. 116/117, 1992, p. 407-440.

PETRONE, Maria Thereza. A lavoura canavieira em São Paulo: expansão e declínio 1765-1851 [tese de 1964]. São Paulo: Difel, 1968.

PINK, Edmund. São Paulo de Edmund Pink. São Paulo: Bovespa, 2000.

PORTA, Paula (org.). História da cidade de São Paulo, vol. 2. São Paulo: Paz e Terra, 2004.

PUNTSCHART, William. Negócios e negociantes paulistas: 1808-1822. Tese de doutorado, Faculdade de Filosofia, Letras e Ciências Humanas, Universidade de São Paulo, 1998.

RABELLO, Elizabeth Darwiche. Os comerciantes na sociedade paulistana na primeira metade do século XIX. Assis, 1988. Tese de livre docência, FCL-Unesp. RICUPERO, Luís Valente de O. (org.). A abertura dos portos. São Paulo: Senac, 2007. ROCHE, Daniel. Histoire des choses banales: naissance de la consommation dans les sociétés traditionnelles (XVIIe-XIXe siècle). [Paris]: Fayard, 1997.

SAINT-HILAIRE, Auguste de. Viagem à província de São Paulo e resumos das viagens ao Brasil, Província Cisplatina e Missões do Paraguai (1819-1822). Tradução de Rubens Borba de Morais. São Paulo: Edusp/Martins, 1972.

SALGADO, Graça (org.). Fiscais e meirinhos: a administração no Brasil colonial. Rio de Janeiro: Nova Fronteira, 1985.

SAMPAIO, Teodoro. São Paulo no século XIX e outros ciclos históricos. $2^{\mathrm{a}}$ ed. Petrópolis: Vozes, 1978.

SÃO PAULO. Actas da Camara Municipal de São Paulo. São Paulo: A. Municipal; Piratininga, 1921.

SÃO PAULO. Registro geral da Camara Municipal de São Paulo. São Paulo: A. Municipal de São Paulo; Piratininga, 1921/22.

SILVA, Joaquim Norberto de Souza e. Investigações sobre os recenseamentos da população geral do Império, e Resumo histórico dos inquéritos censitários 
realizados no Brasil. São Paulo: IPE, 1986.

SILVA, Maria Beatriz Nizza da. O comércio de livros de Portugal para o Brasil e a censura. Revista do Instituto Histórico e Geográfico Brasileiro. ano 164, $\mathrm{n}^{\circ}$ 419, abril/jun. 2003, p. 195-211.

SINGER, Paul. Desenvolvimento econômico e evolução urbana: análise da evolução econômica de São Paulo, Blumenau, Porto Alegre e Belo Horizonte e Recife. São Paulo: Nacional, 1968.

SIRIANI, Sílvia Cristina Lambert. Uma São Paulo alemã: vida quotidiana dos imigrantes germânicos na região da capital (1827-1889). São Paulo: Daesp/Imesp, 2003.

TAUNAY, Affonso de E. História da cidade de São Paulo no séc. XVIII. Vol. II (1765-1801). São Paulo: Dep. Cultura - Div. Arq. Hist., 1951.

TAUNAY, Affonso de E. História colonial da cidade de São Paulo no século XIX. Vol. III [1801-22]. São Paulo: Dep. Cultura [1956].

TAUNAY, Affonso de E. História da cidade de São Paulo sob o império. Vol. IV [1822-31]. São Paulo: Dep. Cultura [1956].

TAUNAY, Affonso de E. História da cidade de São Paulo sob o Império. Vol. V [1831-42]. São Paulo: Publicação da Divisão do Arquivo Histórico, 1961.

TAUNAY, Affonso de E. História da cidade de São Paulo sob o Império. Vol. VI [1842-54]. São Paulo: Dep. Patr. Hist., Div. Arq. Hist., 1977.

\section{Eletrônicos:}

ABREU, Márcia. Quem lia no Rio de Janeiro? In: CONGRESSO BRASILEIRO DE COMUNICAÇÃO, 24. Campo Grande, MS. Campo Grande: Intercom, 2001. Disponível em: <http://reposcom.portcom.intercom.org.br/bitstream/1904/4493/1/NP4ABREU.pdf.>. Acesso em: 20/01/2008.

NEVES, Lúcia Maria Bastos P.; FERREIRA, Tania Maria Bessone da Cruz. Livreiros no Rio de Janeiro: intermediários culturais entre Brasil e Portugal ao longo do Oitocentos. Disponível em: $<$ http://www.realgabinete.com.br/coloquio/3_coloquio_outubro/pag > . Acesso em 20/01/2008.

VILLALTA, Luiz Carlos. Bibliotecas privadas e práticas de leitura no Brasil colonial. Disponível em: <http://www.caminhosdoromance.iel.unicamp.br/ estudos/ensaios/bibliotecas-br.pdf>. Acesso: em 28/08/2008. 